OPEN ACCESS

Edited by:

Sandra Merscher,

University of Miami, United States

Reviewed by:

Simon Satchell,

University of Bristol, United Kingdom

Dorin-Bogdan Borza,

Meharry Medical College,

United States

*Correspondence:

Barbara J. Ballermann barbara.ballermann@ualberta.ca

Specialty section: This article was submitted to Nephrology,

a section of the journa

Frontiers in Medicine

Received: 29 August 2021 Accepted: 05 November 2021

Published: 29 November 2021

Citation:

Ballermann BJ, Nyström J and Haraldsson B (2021) The Glomerular

Endothelium Restricts Albumin

Filtration. Front. Med. 8:766689

doi: 10.3389/fmed.2021.766689

\section{The Glomerular Endothelium Restricts Albumin Filtration}

\author{
Barbara J. Ballermann ${ }^{1 *}$, Jenny Nyström ${ }^{2}$ and Börje Haraldsson ${ }^{2}$ \\ ${ }^{1}$ Department of Medicine, University of Alberta, Edmonton, AB, Canada, ${ }^{2}$ Institute of Neuroscience and Physiology, \\ University of Gothenburg, Gothenburg, Sweden
}

Inflammatory activation and/or dysfunction of the glomerular endothelium triggers proteinuria in many systemic and localized vascular disorders. Among them are the thrombotic microangiopathies, many forms of glomerulonephritis, and acute inflammatory episodes like sepsis and COVID-19 illness. Another example is the chronic endothelial dysfunction that develops in cardiovascular disease and in metabolic disorders like diabetes. While the glomerular endothelium is a porous sieve that filters prodigious amounts of water and small solutes, it also bars the bulk of albumin and large plasma proteins from passing into the glomerular filtrate. This endothelial barrier function is ascribed predominantly to the endothelial glycocalyx with its endothelial surface layer, that together form a relatively thick, mucinous coat composed of glycosaminoglycans, proteoglycans, glycolipids, sialomucins and other glycoproteins, as well as secreted and circulating proteins. The glycocalyx/endothelial surface layer not only covers the glomerular endothelium; it extends into the endothelial fenestrae. Some glycocalyx components span or are attached to the apical endothelial cell plasma membrane and form the formal glycocalyx. Other components, including small proteoglycans and circulating proteins like albumin and orosomucoid, form the endothelial surface layer and are bound to the glycocalyx due to weak intermolecular interactions. Indeed, bound plasma albumin is a major constituent of the endothelial surface layer and contributes to its barrier function. A role for glomerular endothelial cells in the barrier of the glomerular capillary wall to protein filtration has been demonstrated by many elegant studies. However, it can only be fully understood in the context of other components, including the glomerular basement membrane, the podocytes and reabsorption of proteins by tubule epithelial cells. Discovery of the precise mechanisms that lead to glycocalyx/endothelial surface layer disruption within glomerular capillaries will hopefully lead to pharmacological interventions that specifically target this important structure.

\footnotetext{
Keywords: endothelial surface layer, endothelial dysfunction, fenestrae, glycocalyx, hyaluronan, permselectivity, proteoglycans, thrombotic microangiopathy
}

\section{INTRODUCTION}

Albuminuria is the hallmark of essentially all disorders affecting renal glomeruli. In some cases, endothelial cell (EC) injury predominates, for instance the hemolytic uremic syndrome (HUS) (1), thrombotic thrombocytopenic purpura (TTP) (2), pre-eclampsia $(3,4)$, and nephrotoxicity due to VEGF inhibitors (5). Transient proteinuria also accompanies generalized EC activation, in 
the presence of sepsis (6) or viral infections (7, 8). Microalbuminuria is a feature of widespread EC dysfunction in diabetes $(9,10)$ and in cardiovascular disease, where it is a predictor of cardiovascular risk (11-19). EC activation and injury also contributes to proteinuria in many glomerulonephritides and vasculitides affecting glomeruli. This review will tackle the question to what extent the glomerular endothelium contributes to the glomerular capillary wall (GCW) barrier preventing filtration of albumin and other circulating macromolecules. It will review the molecular components of this part of the glomerular capillary barrier (GCB) followed by an exploration of some human diseases in which glomerular EC injury or dysfunction leads to proteinuria. Due to space limitations components of the endothelial glycocalyx that govern complement activation, coagulation and inflammatory cell adhesion and transmigration will not be reviewed in detail.

It is useful to recall that without a glomerular barrier to macromolecule filtration, the potential filtered load of albumin would be $3-5 \mathrm{~g} / \mathrm{min}(\sim 4-7 \mathrm{~kg} / 24 \mathrm{~h})$ in human adults, assuming a plasma albumin concentration of $40 \mathrm{~g} / \mathrm{L}$ and a glomerular filtration rate (GFR) in the range of $75-125 \mathrm{ml} / \mathrm{min}$. Given the upper limit for urinary albumin excretion of $30 \mathrm{mg} / 24 \mathrm{~h}$ in normal adults, it follows that $<0.001 \%(\sim 1 / 100,000)$ of the potential filtered load of albumin is excreted in the urine. Indeed, even with severe nephrotic syndrome, urinary albumin loss usually represents $<1 \%$ of the potential filtered load. Thus, extraordinarily effective mechanisms prevent urinary loss of albumin and other circulating macromolecules.

\section{THE GLOMERULAR CAPILLARY WALL BARRIER}

\section{The Glomerular Sieving Coefficient $(\theta)$ for Albumin $\left(g \theta_{\text {Alb }}\right)$ and Other Macromolecules}

The GCW sieving coefficient, g $\theta$, is defined as the ratio of the Bowman's space to plasma concentration for any given molecule. Since the GCW prevents macromolecule filtration despite its large hydraulic conductivity (water permeability), $\mathrm{g} \theta$ for macromolecules is usually much lower than 1 and depends on size, charge, and shape of the macromolecule. It should also be noted that proximal tubule albumin reabsorption contributes to the low urinary albumin concentration. Hence, $\mathrm{g} \theta_{\mathrm{Alb}}$ can only be determined from urinary albumin levels if the modification of urine by proximal tubule cells is blocked. Alternatively, the albumin/tracer concentration in Bowman's space or early proximal tubule must be quantified. Functional models of the GCW (20-24), derived from experimental sieving data for infused tracers like ficoll (25-28), dextran (29-31), albumin (32$34)$ or endogenous circulating proteins $(28,35,36)$, suggest that the GCW functions as a composite gel-like mesh with a high density of pores having a radius in the 45-50 $\AA$ range, a few large pores with radii of $75-155 \AA$, and a negatively charged layer at the blood/endothelial interface with a charge density of $\sim 35-45 \mathrm{mEq} / \mathrm{L}$ (22). Taking into account these experimentally derived parameters, a mathematical model predicted a $\mathrm{g} \theta_{\mathrm{Alb}}$ of $2 \times 10^{-3}$ (a ratio of ultrafiltrate: plasma albumin of 2: 1,000 )
(22). In fairly close agreement, the best measured estimate of ${ }_{\mathrm{g}} \theta_{\mathrm{Alb}}$ obtained by micropuncture in rats was $6.2 \times 10^{-4}(0.62$ : 1,000) (33), and $\mathrm{g} \theta_{\mathrm{Alb}}$ derived from radiolabeled albumin tracer studies (34) was $6 \times 10^{-4}$. More recent quantification of $\theta_{\mathrm{Alb}}$ by intravital two-photon fluorescence microscopy in rats has varied more widely: 0.034 (37), 0.014 (38), 0.002-0.004 (39) and 0.00044 (40). It appears that technical limitations account for some of the higher values by this approach $(39,41)$. Norden et al. (36) studied humans with the Fanconi syndrome due to Dent's disease, in whom proximal tubule albumin reabsorption is negligible, and found that ${ }_{\mathrm{g}} \theta_{\mathrm{Alb}}$ averaged $7.7 \times 10^{-5}$. Similarly, when megalin and cubulin were conditionally deleted in mice $(42,43),{ }_{\mathrm{g}} \theta_{\mathrm{Alb}}$ was estimated at $7.5 \times 10^{-5}$ and $1.7 \times 10^{-5}$, respectively. In such mice, streptozotocin diabetes (43) or superimposed podocin (42) deletion resulted in a significant increase in $g \theta_{\mathrm{Alb}}$. Since proximal tubule uptake of albumin was completely absent in megalin/cubulin deficient mice (42), these data, taken together with those from rats and humans, indicate that $\sim 0.01-0.1 \%$ of plasma albumin passes through the GCW into Bowman's space. In normal humans therefore, an estimated 500-5,000 mg of albumin are filtered each day (44). Proximal tubule uptake then reduces excretion to $<30 \mathrm{mg} /$ day.

\section{Size and Charge Selectivity}

Mathematical models of sieving data $(20,24,25,35,45,46)$ agree that the GCW is best described as a hydrated gel that hinders entry and movement of macromolecules based on size, shape, flexibility and charge $(21,22)$. Gaps in the gel that allow relatively free filtration of water and small solutes are modeled as abundant small "pores" with a molecular radius cutoff in the 45-50 A range. The models include a small number of larger "pores" to account for the transit of a small fraction of large macromolecules. It turns out that the shape and flexibility of macromolecules influence movement through the small, abundant gaps given that large, elongated uncharged carbon nanotubes seem to be filtered relatively freely (47). Recent data furthermore suggest that compression of GCW components against intact podocytes may influence the size of gaps in the gel and therefore the molecular size cutoff (48). Abundant experimental data in animals (25-27, 30, 34, 49-52) and humans $(20,29)$ and ensuing mathematical models $(20,22,27,53-56)$ have concluded that for molecules like albumin whose size is close to the $45-50 \AA$ radius cutoff, negative charge also impedes movement into and through the gel, compared to the same or similar neutral molecule. Conversely, neutralization of negative charges in the GCW with cationic protamine sulfate $(57,58)$, hexadimethrine $(34,59)$ or their removal with neuraminidase/sialidase $(60,61)$ which strip sialic acid from the GCW, all increase albumin excretion rapidly and reversibly. However, because these interventions also cause structural changes in podocytes and glomerular EC, the cause-effect relationship specifically between the reduction in GCW negative charge density and albuminuria was not proven. Nonetheless, infusion of enzymes to destroy negatively charged glycosaminoglycans (GAGs) also increase the fractional clearance of albumin across the GCW $(62,63)$, even without changes in EC or podocyte ultrastructure. By contrast, in isolated GBM, no change in albumin permeability was observed when 
negative charges were neutralized with protamine (64), and the substantial reduction of GBM negative charges due podocytespecific deletion of agrin \pm perlecan (65), or the heparan sulfate glycosyltransferase EXT1 (66) raise albumin excretion only minimally. While a change in ${ }_{\mathrm{g}} \theta_{\mathrm{Alb}}$ in the knockout mice could have been masked by proximal tubule albumin reabsorption, the results nevertheless cast some doubt on the possibility that "fixed negative charges" located in the GBM play a major role in charge selectivity.

\section{Location of the GCW Albumin Barrier}

The first detailed transmission electron microscopy (TEM) studies of glomeruli caused Farquhar (67) to rule out the glomerular endothelium as a component of the barrier because its fenestrae, lacking visible proteinaceous diaphragms, seemed simply too large to restrict anything smaller than circulating cells. Hence, the glomerular basement membrane (GBM) (68) and podocyte filtration slit diaphragms were held to be the main barrier to macromolecule filtration, with charge selectivity assigned to the GBM $(46,69,70)$. This deduction was strengthened by findings of negatively charged sites within the GBM (71-73), congruent functional studies showing charge selectivity of the GCW $(34,51,74)$, and the fact that disorders affecting podocytes or GBM all lead to proteinuria (75).

Nonetheless, the concept that the GBM and podocyte slit diaphragm constitute the main barrier to GCW protein flux cannot be reconciled with the fact that bulk convective transit of macromolecules through wide open glomerular endothelial fenestrae would rapidly clog the filter unless high-capacity mechanisms returned them, intact, to the circulation $(76,77)$. While podocytes endocytose and degrade albumin and other macromolecules (78), this mechanism does not have the capacity to deal with a daily load of albumin in the $4-7 \mathrm{~kg}$ range. Long albumin and immunoglobulin half-lives and a low renal albumin degradation rate (79) are also inconsistent with removal and degradation of massive quantities macromolecules by podocytes. Farquhar (67) suggested that macromolecules pass through the endothelium into the GBM and sub-podocyte space and then are swept into the mesangium. However, bulk transit of plasma proteins through the mesangium back into the circulation has never been demonstrated, and glomerular lymphatics that would be needed to clear them from the mesangium have not been found (80).

It turns out that under physiological conditions, endogenous albumin $(81,82)$, or infused gold-conjugated albumin (68), actually do NOT penetrate glomerular endothelial fenestrae, leading to the more attractive conclusion that a barrier covering the endothelium and extending into endothelial fenestrae retains all but a small fraction of albumin and other large proteins within the circulation. Indeed, disruption of glomerular EC adherens junctions by EC-specific notch1 activation or VEcadherin deletion results in glomerular EC glycocalyx damage and significant proteinuria (83), implying that fully differentiated glomerular EC with intact adherens junctions and glycocalyx are critically important components of the GCW barrier. No doubt, as detailed by comprehensive models of GCW permselectivity $(48,84-87)$, one cannot consider any single GCW component in isolation (88), but the role of the glomerular endothelium in GCW permselectivity, for which data were already accumulating in the 1980's $(9,89)$ is only now becoming widely accepted $(10,53,88,90-95)$.

\section{PHYSICAL STRUCTURE OF THE GLOMERULAR EC GLYCOCALYX AND SURFACE LAYER}

The EC glycocalyx consists of proteoglycans, sialomucins, other glycoproteins and glycolipids, all anchored to EC plasma membrane. Molecules in the EC glycocalyx interact with and extend into the sub-endothelial GBM and into a luminal endothelial surface layer (ESL). The ESL is composed of secreted and circulating molecules that associate reversibly with the luminal EC glycocalyx, forming a hydrated, loose gel-like layer between blood and EC glycocalyx. These delicate EC surface components are destroyed by tissue processing for conventional electron microscopy (EM) due to their hygroscopic nature, and perfusion and oxygenation are required for their stability $(81,96)$. The luminal EC glycocalyx and the ESL were therefore not appreciated until appropriate techniques for their visualization and quantification were developed.

\section{Visualization of the EC Glycocalyx}

With conventional processing for transmission or scanning EM the glomerular endothelium has the appearance of a sieve, with fenestrae $\sim 60-80 \mathrm{~nm}(600-800 \AA)$ in diameter accounting for $\sim 30 \%$ of the glomerular EC surface area. Glomerular EC fenestrae are plasma membrane-lined, transcellular pores that lack the proteinaceous PV-1-based diaphragms observed in most other fenestrated endothelia (97). The size and density of glomerular EC fenestrae accounts for the enormous hydraulic conductivity of the GCW (98). Any decrease in their density and/or size leads to a reduction in GFR, for instance in experimental models of uranyl nitrate (99) and gentamicin (100)induced acute renal failure, streptozotocin induced diabetes (101), and in humans with diabetes (102) and preeclampsia (103).

The radius of glomerular EC fenestrae is much larger than the effective radius of circulating macromolecules that are not filtered, for instance orosomucoid (29 $)$ ), albumin (36 ̊), Transferrin (43 $)$, IgG (55 $\AA), \alpha 2$-macroglobulin $(90 \AA)$ and fibrinogen $(108 \AA)(35,104)$, so they were initially assumed to allow their free convective movement into the GBM. Yet, studies in non-glomerular capillaries had suggested that EC fenestrae are impermeant to macromolecules (104), and Luft (105) found that EC do not present a "naked" surface to circulating plasma, given that perfused electron-dense ruthenium red accumulated on the EC luminal surface revealing an anionic coat. Avashi and Koshy (106) perfused kidneys with ferritin, a multimer $\sim 120 \AA \mathrm{nm}$ in diameter, so much smaller than glomerular EC fenestrae. Cationic ferritin densely decorated the glomerular EC surface and the core of fenestrae and did not penetrate into the GBM. Anionic ferritin was completely excluded from the EC surface and the GBM, indicating that the EC coat excludes negatively charged macromolecules. Furthermore, adhesion of 
cationic ferritin was removed by neuraminidase and reduced by heparinase and hyaluronidase without change in EC or podocyte ultrastructure. The authors concluded that "glomerular endothelial fenestrae are not empty holes" but "are occupied by an anionic matrix that is visualized only following the binding of an electron-dense tracer. In this respect the matrix in the fenestrae is similar to the glycocalyx at the external surface of cells which also remains invisible in unstained preparations" (106). Rostgaard and Qvortrup (96) extended these observations using oxygen-carrying perfusion fixation and tannic acid/uranyl acetate staining. They observed "sieve plugs" in fenestrae of intestinal and peritubular capillary EC, and a similarly stained layer covering the EC. But in glomerular EC the same procedure revealed only a delicate $\sim 300 \mathrm{~nm}$ thick surface coat (96). Hjalmarsson et al. (107) reported a colloidal lanthanum labeled $\sim 60 \mathrm{~nm}$ thick EC glycocalyx that was revealed in oxygen-carrying perfusion fixed, tannic acid-stained tissue. They observed a thicker $\sim 200 \mathrm{~nm}$ coat ascribed to glycocalyx plus ESL. In their study, cupromeronic blue stained tissue showed a semi-ordered proteoglycan network within the fenestrae (107). In glomerular EC, Hegermann (108) recently visualized an amorphous 200$300 \mathrm{~nm}$ thick layer with alcian blue. With cationic colloidal thorium they observed an electron-dense layer that filled the fenestrae, extended from the EC surface by 50 to $300 \mathrm{~nm}$ and was organized into bundles that were about $50 \mathrm{~nm}$ wide at the EC surface, with sub-organization into wider and wider bundles as they moved away from the surface. They concluded that the glycocalyx proper represents bundles of proteoglycans that are anchored to the EC plasma membrane and extend vertically from the cells toward the capillary lumen (Figure 1). These findings are consistent with those by Squire et al. (109) in non-glomerular EC, who reported vertically organized bundles extending from the EC surface, intertwined with horizontal strands forming a lattice with gaps that could account for size-selectivity. Indeed, Fan et al. (110) were able to visualize hyaluronan (HA) and heparan sulfate (HS) at the single molecule level in cultured EC, using stochastic optical reconstruction microscopy (STORM), i.e. a super-resolution imaging technique with a resolution of $20 \times$ $50 \mathrm{~nm}$. They reported that HS bundles extend vertically from the EC surface and are intertwined with horizontally arranged, long HA strands to form an organized lattice-like network on the EC surface $(110,111)$.

\section{Defining the Height of the ESL}

It could still be argued that tissue processing and deposition of electron-dense material for transmission EM could produce artifact that might overestimate the dimensions of the EC glycocalyx and/or might remove the ESL. To assess the thickness of the EC glycocalyx/ESL the zone of exclusion for RBCs or fluorescently labeled tracers above the EC plasma membrane is therefore commonly determined. For instance, in hamster cremasteric muscle capillaries, the exclusion zone for dextran 70 and RBCs was found to be $400-500 \mathrm{~nm}$ (112), and was significantly reduced by hyaluronidase, and partially reconstituted hyaluronan or chondroitin sulfate infusion (113). In renal glomerular capillaries, the zone of exclusion for infused intralipid droplets was $\sim 200 \mathrm{~nm}$ and was also significantly reduced by enzymes that cleave glycosaminoglycans (114) and by elution of ESL components with hypertonic $\mathrm{NaCl}$ (115). Evaluation of the EC glycocalyx/ESL thickness is now a commonly used technique in human clinical research (116) and has helped define changes in the height of the glycocalyx/ESL in disease.

Hence, all EC surfaces are covered by an organized glycocalyx and an associated ESL. These form an anionic surface that results in repulsion of anionic macromolecules as well as the anionic glycocalyx of circulating cells. The anionic EC glycocalyx extends into the fenestrae, forming a semi-permeable matrix that allows rapid filtration of water and small solutes, but not macromolecules. The lattice-like arrangement of the EC coat furthermore suggests that it participates in size-selectivity of the GCW. It is already well-established that immune-activation of EC changes its glycocalyx, breaching the normal glycocalyx/ESL (116), allowing EC interactions with circulating cells and platelets and facilitating thrombosis (117). Under those conditions it is therefore expected that permselectivity is also reduced.

\section{MOLECULAR COMPONENTS OF THE EC GLYCOCALYX}

The EC glycocalyx is composed membrane-anchored proteoglycans and sialomucins that in conjunction with secreted, hyalectin-bound hyaluronan (HA) form an organized, extremely hydrated lattice-like gel. Many membrane-anchored glycoproteins embedded in the glycocalyx serve as receptors for cytokines, growth factors and as counter-receptors for circulating cells (117). The ESL, on the other hand is a concentrated layer of circulating and EC-secreted proteins, glycoproteins, small proteoglycans and other macromolecules, that is in dynamic equilibrium with the circulation (118).

\section{Glycosaminoglycans}

The structure and function of the EC glycocalyx depends critically on its glycosaminoglycan (GAG) composition. GAGs are long, unbranched polymers of repeating disaccharides, each consisting of an amino sugar (N-acetylglucosamine or $\mathrm{N}$ acetylgalactosamine) and either a galactose or uronic acid sugar (Figure 1A). Due to their high hydroxyl and sulfate content, GAGs are negatively charged; they bind large amounts of water, critical for their viscoelastic properties; they repel negatively charged molecules like albumin and they often serve as coreceptors for growth factors and cytokines. In the luminal EC glycocalyx GAGs confer anti-coagulant properties, they repel circulating cells, and they impart the charge barrier to the endothelium. Heparan sulfate (HS), chondroitin sulfate (CS)/dermatan sulfate (DS) and keratan sulfate (KS) GAGs are all assembled on core proteins of distinct proteoglycans. Hyaluronic acid (HA; aka hyaluronan) (119) is the only GAG synthesized outside the Golgi as a stand-alone polysaccharide composed of non-sulfated $\mathrm{N}$-acetylglucosamine/glucuronic acid disaccharide repeats. HS (120), the most abundant GAG in the EC glycocalyx, consists of $\mathrm{N}$-acetylglucosamine/uronic acid repeats, CS GAGs (121) consist of $\mathrm{N}$-acetylgalactosamine/glucuronic acid and 


\section{A \\ etc- \\ Sialylated Oligosaccharide

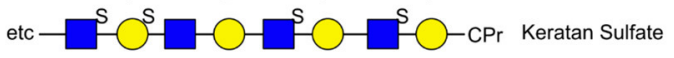

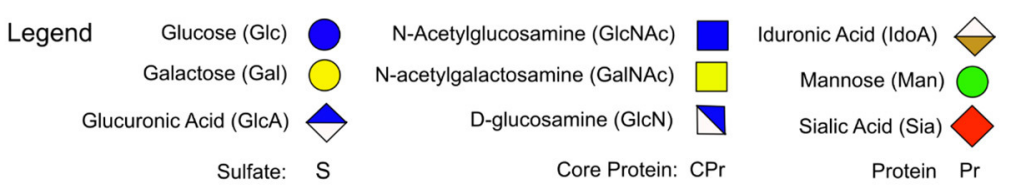

\section{Hyaluronan Synthesis}

D Glycocalyx Components

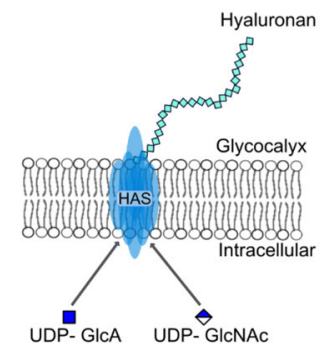

CD44

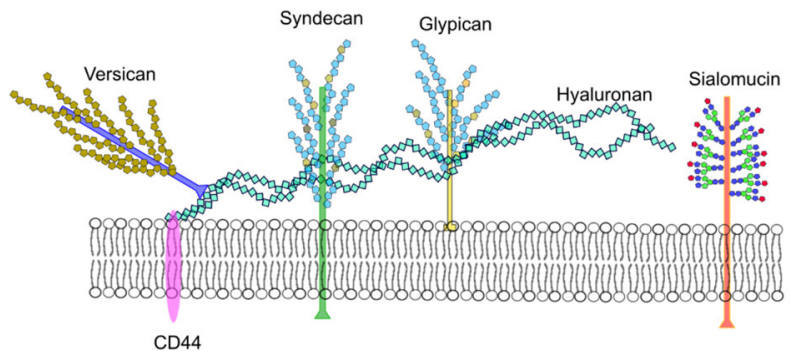

E Secreted/Circulating

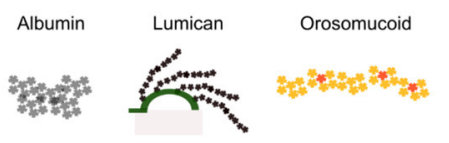

$\mathbf{F}$

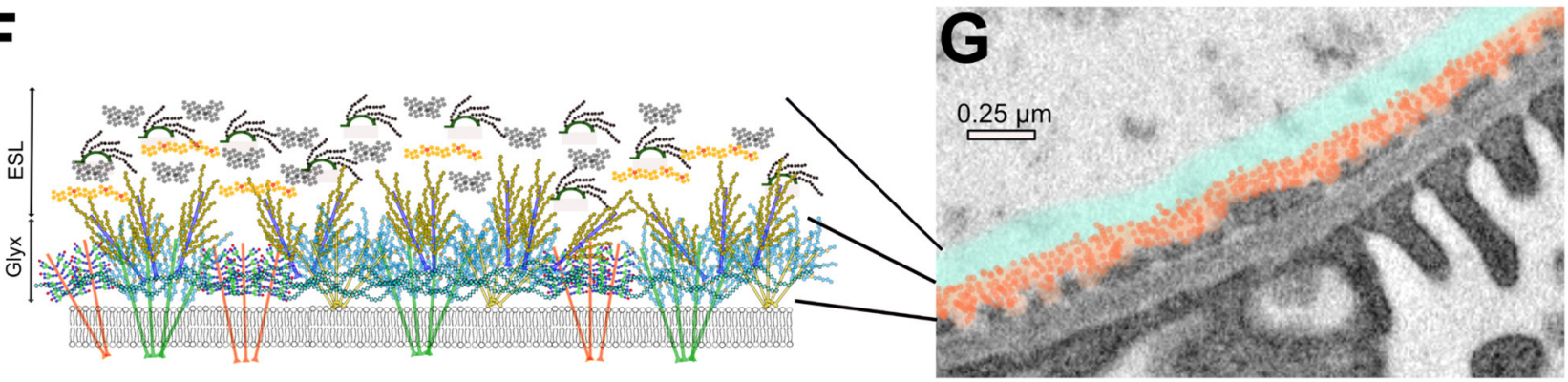

FIGURE 1 | Components of the EC glycocalyx and ESL. (A) Structure of glycosaminoglycan chains. (B) Example of a branched, sialylated oligosaccharide side-chain. (C) Schematic representation of hyaluronan synthase (HAS)-mediated hyaluronan synthesis at the cell membrane. (D) Schematic representation of major EC glycocalyx components. (E) Schematic representation of major ESL components. (F) Artistic representation of the dense, bundled glycocalyx component. (G) Transmission EM image of a glomerular capillary wall with superimposed artistic representation of the glycocalyx (orange) and ESL (blue) thickness.

KS (122). GAGs are composed of N-acetylglucosamine/galactose disaccharide repeats (Figure 1A). Addition of GAG chains to proteoglycans in the Golgi is initiated by specific glucuronyl transferases that covalently couple a bridging tetrasaccharide through O-linkage on serine or threonine or $\mathrm{N}$-linkage on asparagine, followed by elongation of the polysaccharide chain and subsequent position-specific modifications through deacetylation/sulfation and epimerization. For instance, within the initial HS polymer, epimerization converts some of the glucuronic acids to iduronic acid (123) and de-acetylation converts some of the $\mathrm{N}$-acetylglucosamine to glucosamine. Similarly, CS is converted to DS through epimerization of glucuronic to iduronic acid. For proteoglycans, structural and functional diversity is therefore not only due to their different protein cores, but also the GAG type, the number and length of their GAGs, as well as position-specific epimerization and sulfation. Since enzymes involved in GAG-core protein attachment, chain elongation and modification serve multiple proteoglycans, any mutations or deletion in the many enzymes that carry out these functions tend to have different, and often 
more severe phenotypes than mutations or deletion of any one proteoglycan core protein (124).

Cleavage by enzymes that are GAG-specific, namely hyaluronidases, heparinase and chondroitinase have been used extensively to define the functional role of GAGs in the GCW and EC glycocalyx, and shedding of HA and EC cell-surface proteoglycans (125) into the circulation due to endogenous enzymes is used as an indicator of glycocalyx damage $(126,127)$.

\section{Hyaluronic Acid/Hyaluronan}

In vertebrates HA is produced by HA synthases encoded by three distinct genes (HAS1-3). The HA synthases are integral plasma membrane proteins with multiple membrane-spanning domains (Figure 1C). The catalytic site within their hydrophilic core acts as a polymerase, converting soluble intracellular UDP-GLcNAc and UDP-GLcA to polymeric HA, simultaneously extruding the growing polymer it into the extracellular space (128). The length of the HA polymer varies from about 1,000 to 10,000 $\mathrm{kDa}$. The rate of HA synthesis depends on the availability of substrate sugars (129), and conversely, high rates of HA synthesis are associated with a shift of cellular metabolism to glycolysis (130-132). HA binds to cell-surface receptors CD44 (133), RHAMM (receptor hyaluronan mediated motility) (134) and the lymphatic EC receptor LYVE-1. The cytoplasmic domain of CD44, a single pass membrane-spanning receptor, is coupled to cortical actin by ERM (ezrin radixin moesin) proteins (135). The interaction of CD44 with HA enhances EC barrier function (136) and is necessary for transmission of shear force signals that cause Rac1-dependent EC re-orientation (137), enhanced nitric oxide synthesis (138) and increased HAS2 expression (129, 139). In keeping with luminal HA/CD44 interactions, HA loss from the glycocalyx profoundly reduces shear-force induced NO synthesis (140).

HA turnover is rapid and regulated, in part, through HA degradation by hyal-1 and-2 (Hyaluronidase-1 and-2) and by Cemip-1 and-2 (Cell Migration-Inducing hyaluronidase1 and-2; the latter also known as transmembrane protein 2/TMEM2) (131, 141). Hyal-2 is a GPI-anchored plasma membrane-associated enzyme that cleaves CD44-bound HA. The fragments are then internalized by the GAG scavenger receptor HARE (142). The cemid1 (143) and-2 (144) hyaluronidases are single-pass plasma membrane-spanning proteins that degrade extracellular HA into small, bioactive extracellular fragments (oHA). These oligosaccharides modify VEGF signaling in EC (144).

$\mathrm{HA}$ polymers are hydrated with $15 \mathrm{H}_{2} \mathrm{O}$ molecules per disaccharide unit (145). At the apical/luminal EC surface HA interweaves with other components of the glycocalyx/ESL (110, $134)$ and shear stress $(129,146)$ and inflammatory stimuli $(147)$ augment HA accumulation in the EC glycocalyx. HA binds proteoglycans in the hyalectin family (see below) forming large, patterned aggregates. A HA-versican lattice may in fact account, at least in part, for the semi-ordered appearance of the apical EC glycocalyx $(108,109)$, and perhaps also contribute to sizeselectivity of the GCW.

In systemic microvessels, destruction of HA by hyaluronidase markedly reduces the height of the EC glycocalyx and its macromolecular barrier function (113). Similarly, in glomerular capillaries the height of the EC glycocalyx is reduced by hyaluronidase infusion along with an increase in the fractional excretion of albumin (114). EC-specific, conditional HAS2 deletion in mice reduced glomerular EC HA and cationic ferritin labeling, along with progressive proteinuria, glomerular EC ultrastructure changes and capillary involution (148). Conversely, in the mouse streptozotocin model of diabetes deletion of the HYAL1 gene reduced hyaluronidase activity, preserved the EC glycocalyx and was associated with less glomerular barrier disruption than in wild-type mice (149). These findings are consistent with those in diabetic patients, where higher levels of circulating HA and hyaluronidase were found to be associated with the development of microalbuminuria $(150,151)$, and where endothelial glycocalyx disruption was associated with a substantial reduction in glomerular endothelial HA content (148).

\section{Endothelial Proteoglycans}

Among many glycosylated proteins, proteoglycans are distinguished by their very long, unbranched, sulfated GAG sidechains usually accounting for at least $60 \%$ of their molecular mass, the exception being perlecan, where the GAG chains are a minor component (see below). Classification of distinct proteoglycans is based on the structure of their protein core, the type and number of associated GAG chains, and their molecular interaction profile. Some proteoglycans are integral membranespanning proteins, some are covalently bound to the outer leaflet of the plasma membrane by GPI (glycosylphosphatidylinositol) anchors, and others are secreted. The principal structural glycocalyx proteoglycans in EC are membrane-spanning syndecans, GPI-anchored glypicans and secreted perlecan and versican. Other small, secreted proteoglycans are produced by EC and participate in defining the dynamic EC phenotype. In addition to their GAG chains, proteoglycans can also be modified by branched oligosaccharide side chains, some terminated by sialic acid. There currently is a paucity of data on potential effects of such modifications on the properties of the glycocalyx/ESL. Thus, future studies are needed to better understand their impact on glomerular permselectivity.

\section{Syndecans}

Syndecans 1-4 are ubiquitous single-pass type I membranespanning proteoglycans, with core proteins in the $20-45 \mathrm{kDa}$ range. The extracellular domains of syndecan-1 and -3 are decorated by HS and CS GAGs, while syndecans- 2 and -4 contain only HS GAGs. Their GAG-rich extracellular domains interact with many growth factors, cytokines and extracellular matrix proteins transmitting signals via their cytoplasmic domains down several intracellular pathways (152-155). In EC, syndecans act as co-receptors promoting angiogenesis (156-158) and the EC response to inflammation (158-160). At the basal surface of angiogenic EC, syndecan-1 is part of integrin/focal adhesion complex $(157,161)$ that promotes angiogenesis, and both syndecan-4 (162) and syndecan-1 (163) participate in the EC remodeling response to shear stress. All syndecans are expressed in cultured glomerular EC where they are part of the 
luminal/apical EC glycocalyx $(127,159,164)$. In Zebrafish in vivo, syndecan-3 is the main syndecan in glomerular EC (165).

The EC response to inflammation is characterized by upregulation of syndecan expression $(158,160)$ and shedding of syndecans from the glycocalyx into the circulation $(125,166)$, resulting in less syndecan in the ESL (167). The increased mRNA expression levels may be compensatory of the increased shedding of proteins (168). Syndecan shedding is observed in response to thrombin activation $(166,169)$, hypoxia, ischemiareperfusion injury (170) and in preeclampsia (171). In glomerular EC, syndecan- 4 shedding in response to IL- $1 \beta$ activation and was mediated by matrix metalloproteinase-9 (127). Proteasedependent syndecan shedding $(126,127,160,172,173)$ produces bioactive soluble syndecan fragments generally inhibiting the inflammatory response (160). Syndecan shedding is now widely recognized as a biomarker of EC glycocalyx disruption (174) and is associated with a reduced glycocalyx thickness and a reduced barrier function resulting in edema formation and albuminuria (175). While cleavage of HS and CS GAGs reduces the size and barrier of the glycocalyx in glomerular and nonglomerular EC, endothelial-specific deletion of syndecan 1 alone only reduced the height of the glycocalyx but did not change its barrier function (176). In cultured EC, sphingosine-1-phosphate (S1P) rescued shedding of syndecan-1 and glycocalyx GAGs due to plasma protein depletion (177). Since S1P is presented to EC by albumin, this was taken to indicate that the effect of serum proteins on glycocalyx integrity may be mediated by S1P $(178,179)$. Substantial syndecan shedding along with thinning of the EC glycocalyx has also been reported in patients with CKD where it correlates with markers of EC dysfunction (180). Hence, the syndecans along with their HS GAGs are major contributors to the EC glycocalyx thickness. Their shedding signals EC glycocalyx dysfunction along with a reduction in the EC glycocalyx barrier to protein filtration.

\section{Glypicans}

Glypicans $(124,181)$ are proteoglycans composed of $60-70 \mathrm{kDa}$ core proteins with heparan sulfate GAG side chains. The Ctermini of glypicans are attached to the plasma membrane through GPI anchors. There are 6 glypican genes (GPC16), among these, glypican-1 is predominant in EC (182). Glypicans enhance fibroblast growth factor (FGF) (183), and VGEF-dependent (182) cell proliferation, in turn stimulating angiogenesis. Due to its GPI anchor, glypican-1 localizes to lipid microdomains often referred to as rafts, and clusters in response to shear stress in EC caveolae (184), where it activates NO synthesis in response to traction forces $(163,185,186)$. In glypican-deficient mice, NO synthesis is markedly reduced, in keeping with a major role of EC glypican-1 in signaling $\mathrm{NO}$ synthesis (187). Conversely, the HS GAGs of glypican-1 undergo non-enzymatic cleavage from their core protein by NO (124), resulting in glypican-1 endocytosis and recycling (188). Reduced NO synthesis, a hallmark of EC dysfunction in inflammatory diseases and under conditions of increased oxidative stress, has therefore been attributed to reduced EC glycocalyx glypican-1 function (174).

\section{Versican}

Versican and aggrecan, both abundant in the vasculature, belong to the family of hyalectins (189), large, secreted CScontaining proteoglycans that bind hyaluronan with high affinity forming aggregates with substantial viscoelastic strength (190). Like other proteoglycans, hyalectin GAGs bind growth factors and cytokines, regulating their interaction with cell-surface receptors, and their cleavage by proteases releases bioactive fragments (189). In EC, synthesis of an HA-binding CS proteoglycan by EC was first demonstrated by Morita et al. (191) and versican was subsequently shown to be produced by EC (192), including glomerular EC (164). Aggrecan is synthesized by vascular smooth muscle cells and myofibroblasts (193) but evidence for its synthesis by EC is lacking so far. While versican is part of the subendothelial matrix where it binds the matrix protein fibulin (194), it also localizes to the apical/luminal EC surface where it binds hyaluronan which, in turn, attaches to cell-surface CD44 (189). Co-localization of CS GAGs and hyaluronan on the apical surface of immortalized glomerular EC in culture has been documented and removal of CS reduced the transendothelial resistance and increased apical to basal albumin flux (195) indicating a role for CS containing proteoglycans in the EC barrier function. In zebrafish, versican was observed in glomerular EC and podocytes, and its knockdown reduced the barrier function of the GCW (165). Versican synthesis by cultured glomerular EC is inhibited by puromycin aminonucleoside (164). Adriamycin in vivo similarly reduced glomerular versican expression along with a profound loss of glomerular EC glycocalyx/ESL thickness and an increase in the sieving coefficient for albumin due to a charge defect (196). A similar charge defect was associated with reduced glomerular versican expression in diabetic mice (197). In aggregate, these studies indicate that versican is part of the glycocalyx that surrounds EC, and that its GAGs participate in glomerular charge selectivity.

\section{Perlecan}

Perlecan is a massive proteoglycan whose protein core alone has a molecular mass of $\sim 470 \mathrm{kDa}$ and is composed of 5 distinct functional domains $(152,198)$. Three GAG chains, which can be $\mathrm{HS}$, CS or KS, decorate the N-terminal perlecan domain, each contributing another $\sim 40 \mathrm{kDa}$ to the overall molecular mass. The C-terminus of perlecan interacts with transmembrane integrins. Produced by all EC $(164,199)$, perlecan carries only HS GAGs in EC, and is secreted into the subendothelial matrix and the EC apical/luminal surface layer $(199,200)$. A host of molecular interactions specific for each of the 5 perlecan domains have been described, and proteolytic cleavage of perlecan produces bioactive fragments $(152,198,199)$. Relevant for EC is the proangiogenic action of intact perlecan and the anti-angiogenic function of endorepellin, the cleaved, soluble perlecan V domain that inhibits VEGFR2 in EC (199). Perlecan functions as a mechanosensor at the surface of chondrocytes where it transmits shear stress signals produced by compression-induced fluid flow in cartilage canaliculi. A similar function as a shear stress sensor has been proposed for EC $(152,198)$, though is no proven so far. Perlecan deletion in mice is lethal, but the knock-out mice 
are viable when perlecan is selectively rescued in chondrocytes (201). In that model, EC perlecan is required for the appropriate formation of EC cel-cell junctions and pericyte recruitment by brain microvessels (201). In mice carrying a perlecan mutation that precludes attachment of its GAG chains, no abnormalities in glomerular structure or function were detected, and the macromolecular GCW barrier function remained intact (65). So, while perlecan is a major proteoglycan produced by EC, its GAG components do not seem to confer charge-selective properties to the GCW, and absence of perlecan GAGs do not impair glomerular EC ultrastructure. Nonetheless, perlecan shedding from the glycocalyx has been observed under conditions of EC dysfunction. For instance, in patients with severe preeclampsia circulating perlecan levels are significantly higher than in normal pregnant women (202).

\section{Small Leucine-Rich Proteoglycan Family}

The (SLRP) family (203) includes decorin, biglycan and lumican all produced by EC, including glomerular EC in culture (164) and in vivo $(204,205)$. These SLRPs are characterized by a small core protein $(\sim 40 \mathrm{kDa})$ with few CS/DS or KS GAG chains (206). They are secreted into the subendothelial matrix where they interact directly with collagen, aiding in the structural matrix organization and EC adhesion and migration (207). Lumican is found in a high-salt eluate of renal vessels $(115,208)$, suggesting that it is a major component of the ESL. The SLRPs interact with, and regulate the function of TGF- $\beta$ and its family members and other growth factors (203). Most recently decorin was shown to activate the autophagy pathway in EC (209). Decorin, biglycan and lumican null mice have been created, but so far roles in defining glomerular EC ultrastructure, thickness of the glomerular EC coat, or glomerular permselectivity have not been reported.

\section{Endothelial Specific Molecule-1}

Endothelial specific molecule-1 (ESM1, aka endocan) is a small, secreted EC-specific CS/DS proteoglycan (210) induced by TNF$\alpha$ and IL-1 $\beta$. It interacts with integrins and growth factors and is involved in regulating angiogenesis. Its circulating levels increase and correlate with microalbuminuria in patients with hypertension (211).

\section{Serglycin}

Serglycin is a small proteoglycan expressed by EC, and hematopoietic cells $(212,213)$ whose name refers to a serine/glycine repeat domain that supports attachment of several GAGs through O-linked glycation on Ser residues. At baseline, serglycin is sequestered in intracellular granules and participates in granule mobilization in response to inflammatory stimuli. In activated EC, serglycin promotes cell-surface localization of chemokine receptors $(213,214)$.

\section{Endothelial Sialomucins}

Sialomucins in the EC glycocalyx are integral plasma membrane glycoproteins each with a single membrane-spanning domain, a large extracellular "mucin" domain and a cytoplasmic domain that interacts with cortical actin via ERM (ezrin radixin moesin) proteins. Mucin domains are ser/thr/pro-rich regions densely decorated by O-glycans initiated by core $1 \beta 1,3$ galatosyltransferase (215) and containing terminal sialic acids. Silomucins largely accounting for the high sialic acid content of the EC glycocalyx. Several sialomucins, including podocalyxin $(216,217)$, endoglycan (218) (aka podocalyxin 2), CD34 (219), and endomucin $(220,221)$ are expressed by EC, while podoplanin is restricted to lymphatic EC (215). Sialomucins are sorted to the apical/luminal surface $(216,222)$ of EC where they play a repulsive role during embryonic vascular lumen formation (222, 223) and they repel circulating cells by virtue of their negative charge (219). EC sialomucins (219) play a role in hematopoietic precursor trafficking (219) and as counter-receptors for Lselectin, though this latter function requires modification of the O-glycan by carbohydrate 6-O-sulfotransferase restricted to high endothelial venules (224). The potential role of sialomucins the glomerular EC barrier to macromolecule flux has only been studied indirectly, through infusion of neuraminidase $(60,61,95,106,225-227)$, which removes sialic acid from the GCW and consistently results in albuminuria. However, since podocytes also express the sialomucins podocalyxin and podoplanin, it is possible that the neuraminidase-induced GCW barrier results from stripping of sialic acid from both, EC and podocyte sialomucins. Even so, in cultured EC, podocalyxin knock-down markedly reduces the trans-endothelial resistance. EC-specific podocalyxin deletion in mice alters EC structure and reduces the EC barrier function in lung and brain in the presence of pro-inflammatory stimuli (228-230). Global podocalxyin deletion in mice is lethal due to a major podocyte defect, though in these mice glomerular EC are also thickened and lack fenestrae (231). Conditional deletion of the core 1 $\beta 1,3$ galatosyltransferase, critical for sialylation of all sialomucins, results in marked albuminuria (232). Finally, in children with streptococcus pneumoniae associated HUS, neuraminidasemediated removal of sialic acid from sialoglycoproteins in the EC glycocalyx likely plays a significant role in triggering intravascular coagulation, hemolysis, and acute renal failure accompanied by proteinuria (233).

\section{CIRCULATING PROTEINS IN THE ENDOTHELIAL SURFACE LAYER}

The ESL refers to a layer of macromolecules that merges with glycocalyx GAGs substantially increasing the separation of freely flowing plasma from the EC surfce (118). The height of glycocalyx with ESL is $\sim 250 \mathrm{~nm}$ in glomerular capillaries (114), and up to $500-1,000 \mathrm{~nm}$ in systemic vessels (113). The loosely bound macromolecules of the ESL, some secreted by EC, others derived from circulating blood (Figure 1), are in dynamic equilibrium with flowing plasma and are concentrated in the zone above the glycocalyx due to the sieving effect.

The precise composition of the ESL is not known, though it contains albumin, orosomucoid, lipoproteins, lipases, complement components, and small proteoglycans secreted by EC, like lumican (115). Removal of GAGs and terminal sialic acids disrupts the interactions of ESL components with the 
glycocalyx proper, causing glycocalyx collapse and a reduction in the zone of exclusion.

\section{Albumin}

Produced by the liver at a rate of $\sim 10 \mathrm{~g} /$ day, albumin is the most abundant circulating protein, with normal plasma concentrations of $35-50 \mathrm{~g} / \mathrm{L}$ and a half-life of 19-20 days. Encoded by a single gene, human albumin is secreted as a monomeric nonglycosylated polypeptide consisting of 585 amino acids (MW $\sim 66.5$ ). A relatively high content of acidic amino acids and fatty acid binding result in an estimated isoelectric point of 4.75.8 (234). Hence, in physiologic solutions albumin is negatively charged. Structural analyses (235-238) show that albumin is not a simple sphere, but that it consists of 3 major domains, each containing subdomains, with 17 intramolecular disulfide bonds contributing to 3D folding. Normally, albumin assumes a heart-shaped triangular structure (237) with a hydrodynamic radius of $36.2 \AA$, though it can assume other conformations depending on $\mathrm{pH}$, including an expanded cigar-like shape with a hydrodynamic radius of $61.5 \AA$ (238). Were it not for its negative charge, the structure of albumin and its ability to take on different conformations suggest it could penetrate a meshwork with mean pore radii in the range of 40-60 $\AA$, like the glomerular capillary wall (20). The albumin monomer contains hydrophobic pockets that bind many lipophilic substances, among them endogenous fatty acids, steroid hormones, thyroid hormone, bilirubin, vitamins, and phytochemicals. Its binding affinity for many drugs and its potential as drug carrier have been extensively investigated. Non-enzymatic glycation of albumin results in conformational changes that alter its interaction with endogenous substances and drugs, increase its half-life and reduce formation of albumin aggregates $(38,239)$.

While albumin flux across the endothelial glycocalyx and ESL is highly restricted (81), albumin also associates with the ESL and alters the endothelial barrier function. In vitro NMR studies show interactions between albumin and hyaluronan resulting in albumin/hyaluronan complexes that hinder the mobility of albumin in solution (240). Albumin binds to immobilized artificial glycocalyx composed of hyaluronan, heparan sulfate and chondroitin sulfate GAGS though its binding affinity is low (241). In cultured EC, albumin similarly associates with the EC cell surface in a reversible fashion (242), and in perfused frog mesenteric microvessels (243) endogenous albumin was observed in a $\sim 200 \mathrm{~nm}$ thick layer covering the EC surface (243). Likewise, albumin associates with lung EC glycocalyx; Lowering perfusate plasma protein/albumin content significantly increased penetration of endogenous, negatively charged ferritin into the vessel wall (244). Similarly, in isolated dog glomeruli, lowering perfusate albumin concentrations raised GFR not only due to a reduction in the colloid osmotic pressure, but also due to an increase in the hydraulic conductivity of the glomerular capillary wall (245). A similar effect of albumin on the hydraulic conductivity was also reported for non-glomerular vessels in frog (225) and rabbit (246). Finally, in the analbuminemic Nagase rats, the negative charge density of the glomerular EC coat was reduced, with enhanced penetration by macromolecules in the $60-90 \mathrm{kDa}$ range both corrected by albumin infusion (247).
In tracer studies, enhanced flux of glycated albumin across the EC layer has been reported (248), though by two-photon microscopy its GCW sieving coefficient was not different than that of native albumin (38). Instead, reduced uptake of glycated albumin by the neonatal $\mathrm{Fc}$ receptors $(\mathrm{FcRn})$ in proximal tubule cells enhanced its renal excretion (38). Thus, in vitro and in vivo studies all indicate that albumin associates with the EC coat, reducing the filtration coefficient and the trans-endothelial flux of macromolecules (179). The relatively low affinity of albumin for glycocalyx/ESL components furthermore suggests that bound albumin is constantly exchanged with circulating albumin. Given that albumin binds the bioactive lipid S1P (178, 249 ), and that S1P protects the EC glycocalyx (250), it is likely that albumin not only changes the function of the endothelial glycocalyx/ESL through physical binding, but that it also delivers mediators to the EC that alter glycocalyx/ESL synthesis and degradation.

\section{Orosomucoid}

In humans, orosomucoids are produced by two distinct genes, ORM1 and 2. Orosomucoids are sialylated, negatively charged circulating glycoproteins produced mainly by the liver (251) but also by EC (252). Basal plasma concentrations are in the range of $1 \mathrm{~g} / \mathrm{L}$. Orosomucoid synthesis is strongly induced by inflammatory stimuli, like lysopolysaccharide (LPS), and interleukins- 1 and -6 ; they are therefore considered to be acute phase reactants (251). Orosomucoid core proteins $(\sim 21.5 \mathrm{kDa})$ undergo complex and variable glycosylation prior to secretion, increasing their molecular mass to $\sim 44 \mathrm{kDa}$, and resulting in a high sialic acid content. Orosomucoid glycosylation is modified in response to acute inflammatory stimuli, increasing the density of sialyl-Lewis $\times$ epitopes $\left(\mathrm{sLe}^{\mathrm{x}}\right)$ that can interact with EC surface P- and E-selectins $(253,254)$. In cultured EC, orosomucoid 1 binds both high affinity, relatively low capacity cell surface receptors, and lower affinity, extremely high capacity binding sites (255). The former likely represent EC P- and L-selectin binding, the latter association with the ESL, increasing the ESL negative charge density (256). Pertinent to this discussion, orosomucoid reduces the flux of albumin across rat hindlimb microvessels (257), and lactalbumin flux across frog mesenteric vessels (258) and the blood brain barrier (259). In the kidney, perfusate containing orosomucoid reduces the fractional clearance of albumin $(32,260)$, and administration of of orosomucoid protects rats from puromycin aminonucleosideinduced albuminuria and GFR loss (261). Hence, orosomucoid, which is not filtered but associates with the surface of EC, reduces albumin flux across EC, by increasing the ESL negative charge density. Orosomucoid-dependent modulation of inflammatory cell recruitment and EC transmigration may also contribute to the renal response to injury. For instance, urinary excretion of orosomucoid increases in patients with type 2 diabetes and may be a biomarker for EC dysfunction due to low-grade inflammation (262). In triple (ORM1-3) knockout mice (unlike humans, mice have 3 ORM genes), enhanced inflammation and a greater susceptibility to renal fibrosis in the unilateral ureteral obstruction (263) and acute ischemia-reperfusion (264) models have been reported. At this time, quantitative 
glomerular permselectivity studies in ORM deficient mice are lacking.

\section{DISRUPTION OF THE EC MACROMOLECULAR BARRIER IN DISEASE}

A thorough understanding of the GCW barrier not only requires knowledge of its composition, still incomplete, but also its dynamic regulation. The complete EC barrier consists not only of the glycocalyx/ESL covering the EC surface and filling the fenestrae, but also cell-cell junctions, and the subendothelial glycocalyx/matrix. Even at equilibrium, all constituents of the EC glycocalyx and ESL are continually turning over through tightly regulated mechanisms. They are subject to, and participate in responses to shear and compression forces, to soluble mediators and to signals from podocytes (265-267). Mechanisms disrupting the barrier can range from EC dysfunction observed in the metabolic syndrome and cardiovascular disease, to EC dedifferentiation upon withdrawal of critical stimuli like VEGF, observed in preeclampsia, to EC activation by inflammatory stimuli in HUS, TTP and sepsis, all the way to destruction of the $\mathrm{EC}$ in some forms of glomerulonephritis and vasculitis.

\section{Microalbuminuria Reflects Generalized EC Dysfunction}

EC dysfunction, characterized by diminished flow-mediated vasodilation due to reduced endothelial NO production, signals generalized EC abnormalities in patients with cardiovascular disease, the metabolic syndrome, diabetes and chronic kidney disease $(10,174,265,268)$. Microalbuminuria is strongly associated with EC dysfunction (269), predicts cardiovascular morbidity (19) and is one of the earliest indicators of generalized, chronic EC injury (9). Note again that microalbuminuria tends to underestimate the GCW defect, due to proximal tubule reabsorption of albumin (79). EC glycocalyx disruption with a substantial reduction in glomerular EC HA content has been documented in patients with diabetic nephropathy (148). In generalized vascular disease, microalbuminuria is associated with a reduction in EC glycocalyx/ESL height and increase in circulating EC glycocalyx components, including hyaluronan $(149,270)$ and proteoglycans $(126,150,151,174)$. As EC glycocalyx glypican-1 is required to elicit shear-induced NO synthesis $(184,186)$, it seems likely that glycocalyx degradation is, in fact, the proximate cause of reduced flow-dependent NO synthesis in generalized EC dysfunction. In experimental diabetes, endomucin restored the EC glycocalyx (221, 271), and in human diabetic patients partial restoration of the EC glycocalyx with sulodexide, an orally administered mixture of GAGs, not only lowers blood pressure, but also reduces albuminuria and other diabetic complications (272-276). Hence, microalbuminuria reflects the endothelial barrier defect that accompanies glycocalyx disruption and EC dysfunction in cardiovascular disease, diabetes and chronic kidney disease. The use of GAGs to enhance EC glycocalyx function could well develop into new therapeutic approach. It is important to note that the massive increase in cardiovascular morbidity of dialysis patients is, at least in part, due to chronic EC glycocalyx/ESL dysfunction $(277,278)$.

\section{Albuminuria Reflects Glomerular Endothelial Barrier Dysfunction in Preeclampsia}

Preeclampsia affects $3-5 \%$ of all pregnant women and is associated with substantial risk to baby and mother. Albuminuria and hypertension are the earliest manifestations of preeclampsia. Marked glomerular EC swelling along with loss of glomerular EC fenestrae, also referred to as "glomerular endotheliosis" has long been recognized as the key glomerular abnormality in preeclampsia (279-281). EC abnormalities in preeclampsia, are not restricted to the glomerular endothelium, often involving the choroid plexus as well, and preeclampsia can progress to the full-blown thrombotic microangiopathy of pregnancy (282), the HELLP (hemolysis, elevated liver function tests, low platelets) syndrome. Even so, proteinuria is the main indicator of EC dysfunction in these patients. Glomerular EC differentiation and fenestration depend critically on podocytederived VEGF (283) and endotheliosis lesions are observed in mice with podocyte-specific VEGF haploinsufficiency (284). Also, bone morphogenetic protein-9 (BMP-9) signaling via the endothelial-specific ALK-1/endoglin receptor complex signals EC differentiation $(285,286)$. In patients with preeclampsia, placenta-derived, circulating soluble VEGF receptor and soluble endoglin inhibit VEGF- and BMP-9 signaling pathways leading to glomerular EC de-differentiation $(3,287,288)$. Along with the ultrastructural EC changes, reduced EC glycocalyx/ESL height and shedding of glycocalyx components into the circulation have been documented in preeclampsia $(171,174,202,289)$. The use of VEGF inhibitors to reduce tumor angiogenesis (290) and macular degeneration (5) can evoke a similar syndrome of albuminuria, sometimes in the nephrotic range, and hypertension. It turns out that the human diacylglycerol kinase epsilon (DGKE) mutation (291), a cause of the hemolytic uremic syndrome, also reflects inhibition of VEGF signaling and consequent de-differentiation of glomerular EC (292). Hence, albuminuria in preeclampsia, and in patients treated with VEGF inhibitors, reflects EC dedifferentiation resulting in a breach of the normal glomerular EC barrier to macromolecules.

\section{The Thrombotic Microangiopathies}

Characterized by a vicious cycle of intracapillary thrombus formation, platelet consumption and microangiopathic hemolytic anemia, the thrombotic microangiopathies all involve EC activation (293), whether by Shiga toxin (294), COVID-19 $(295,296)$, thrombin, complement components (297) and/or inflammatory cytokines (296). Normally, endogenous inhibitors prevent activation of the coagulation and complement cascades at the EC surface and soluble EC-derived mediators like NO and prostacyclin block platelet activation. As part of the luminal EC glycocalyx, integral membrane-spanning thrombomodulin binds and inhibits thrombin, and stimulates protein $C$, which actively cleaves components of the coagulation cascade (298), by binding 
to the EC protein $\mathrm{C}$ receptor. Tissue factor pathway inhibitor (TFPI) (299) and complement factor H (CFH) (300) both bind HS GAGs in the EC glycocalyx/ESL, inhibiting local thrombin and complement activation, respectively. EC activation also results in reduced $\mathrm{NO}$ and prostacyclin production, de novo expression of membrane-anchored tissue factor, release of TFPI and CFH from the EC surface by heparinases (300), and mobilization of P-selectin and von Willebrand Factor (vWF) to capture platelets (301). It follows that even minor causes of EC activation, for instance a viral infection, can trigger run-away intravascular thrombosis in patients with genetic mutations or neutralizing antibodies to thrombomodulin (298), ADAMTS13 (297, 302), or to complement inhibitors (293). Loss of sialic acid EC glycocalyx by pneumococcal derived neuraminidase can also trigger the hemolytic uremic syndrome in children (233), as can reduced VEGF signaling due to loss of function mutations in diacylglycerol kinase $(291,292)$. While albuminuria is common in patients with these disorders, end-organ damage due to microvascular thrombosis are clinically more significant.

\section{EC Glycocalyx Disruption in Critically ill Patients}

Trauma, cardiovascular surgery, septic shock (303) and more recently in critical illness due to $\operatorname{COVID}-19$ (7, 295), all are associated with generalized EC activation and EC glycocalyx disruption. While proteinuria is common in critically ill patients $(6,8)$, pulmonary and brain EC barrier disruption tend to have greater relevance for outcomes and therapy in these patients. Endothelial cell activation by inflammatory mediators, among them TNF- $\alpha$ and Il1- $\beta$, results in shedding of EC glycocalyx components exposing cell-surface adhesion molecules that enable the initial capture and rolling of leukocytes on the endothelium and integrin-dependent leukocyte transmigration (304). EC glycocalyx disruption also promotes platelet adhesion and reduces the anti-coagulant and fibrinolytic activity of the EC surface (305). Even so, a recent metanalysis concluded that while EC glycocalyx shedding is common in critically ill patients, it does not distinguish between various causes and is not consistently associated with "vascular leak" (116). Similarly, albuminuria in this setting is a non-specific marker of EC glycocalyx dysfunction.

\section{SUMMARY AND FUTURE CONSIDERATIONS}

The glomerular endothelium is a critically important component of the size- and charge-selective GCW barrier. Only a very

\section{REFERENCES}

1. Brasher C, Siegler RL. The hemolytic-uremic syndrome. West J Med. (1981) 134:193-7.

2. Tsai HM. The kidney in thrombotic thrombocytopenic purpura. Minerva Med. (2007) 98:731-47.

3. Phipps EA, Thadhani R, Benzing T, Karumanchi SA. Pre-eclampsia: pathogenesis, novel diagnostics and therapies. Nat Rev Nephrol. (2019) 15:275-89. doi: 10.1038/s41581-019-0119-6

4. Roberts JM, Taylor RN, Musci TJ, Rodgers GM, Hubel CA, McLaughlin MK. Preeclampsia: an endothelial cell disorder. Am small fraction of circulating albumin and other macromolecules can penetrate glomerular EC to reach the underlying GBM and sub-podocyte space. While glomerular EC fenestrae support filtration of massive volumes of water and small solutes, they are not permeable to larger plasma proteins due to a negatively charged, organized glycocalyx and ESL that covers the EC surface and fills the fenestrae. This pericellular environment not only serves as a physical barrier to macromolecules, it also controls the activity of many mediators, cytokines, growth factors, complement and coagulation cascades, and circulating cell and platelet repulsion/adhesion. Glycocalyx degradation in disorders that cause wide-spread EC dysfunction and/or activation, like the metabolic syndrome, diabetes, sepsis and other forms of systemic inflammation, result in glycocalyx degradation and proteinuria. More specific insults like VEGF pathway interruption and localized activation of complement and coagulation cascades can cause somewhat more restricted glomerular EC injury. Many components of the EC glycocalyx/ESL are known, but it is expected that there are unique aspects of its composition and organization in glomerular EC. To define these in health and disease represents a major, but important challenge for the future, given that most glycocalyx/ESL components are ubiquitous, and their function is not just defined by protein expression, but also by many position-specific polysaccharide modifications.

\section{AUTHOR CONTRIBUTIONS}

$\mathrm{BB}$ performed the literature review and wrote this manuscript. $\mathrm{JN}$ and $\mathrm{BH}$ have contributed fundamental research and insights to this topic and reviewed/critiqued the final manuscript. All authors contributed to the article and approved the submitted version.

\section{FUNDING}

This work was funded by Principal Author's laboratory was from the Canadian Institutes of Health Research (\#\#427186), the Natural Sciences and Engineering Research Council of Canada (\#NSERC RGPIN-2016-05609), and the Heart and Stroke Foundation of Canada (\#HSFC G-16-00013991).

\section{SUPPLEMENTARY MATERIAL}

The Supplementary Material for this article can be found online at: https://www.frontiersin.org/articles/10.3389/fmed. 2021.766689/full\#supplementary-material

J Obstet Gynecol. (1989) 161:1200-4. doi: 10.1016/0002-9378(89)90 665-0

5. Hanna RM, Barsoum M, Arman F, Selamet U, Hasnain H, Kurtz I. Nephrotoxicity induced by intravitreal vascular endothelial growth factor inhibitors: emerging evidence. Kidney Int. (2019) 96:572-80. doi: 10.1016/j.kint.2019. 02.042

6. Sachdev A, Raheja K, Gupta N, Chugh P. Association of urinary albumin:creatinine ratio with outcome of children with sepsis. Indian J Crit Care Med. (2020) 24:465-72. doi: 10.5005/jp-journals-1007123463 
7. George JA, Khoza S. SARS-CoV-2 infection and the kidneys: an evolving picture. Adv Experim Med Biol. (2021) 1327:10718. doi: 10.1007/978-3-030-71697-4_8

8. Reuben DB, Wachtel TJ, Brown PC, Driscoll JL. Transient proteinuria in emergency medical admissions. N Engl J Med. (1982) 306:10313. doi: 10.1056/NEJM198204293061706

9. Deckert T, Feldt-Rasmussen B, Borch-Johnsen K, Jensen T, KofoedEnevoldsen A. Albuminuria reflects widespread vascular damage. the steno hypothesis. Diabetologia. (1989) 32:219-26. doi: 10.1007/BF00285287

10. Goligorsky MS. Vascular endothelium in diabetes. Am J Physiol Renal Physiol. (2017) 312:F266-F275. doi: 10.1152/ajprenal.00473.2016

11. Chugh A, Bakris GL. Microalbuminuria: what is it? why is it important? what should be done about it? an update. J Clin Hypertens. (2007) 9:196200. doi: 10.1111/j.1524-6175.2007.06445.x

12. Lee SJ, Lee DG. Relationship between kidney dysfunction and ischemic stroke outcomes: albuminuria, but not estimated glomerular filtration rate, is associated with the risk of further vascular events and mortality after stroke. PLoS ONE. (2016) 11:E0155939. doi: 10.1371/journal.pone.0155939

13. Rabelink TJ, de Zeeuw D. The glycocalyx-linking albuminuria with renal and cardiovascular disease. Nat Rev Nephrol. (2015) 11:66776. doi: $10.1038 /$ nrneph. 2015.162

14. Smink PA, Lambers Heerspink HJ, Gansevoort RT, de Jong PE, Hillege HL, Bakker SJ, et al. Albuminuria, estimated GFR, traditional risk factors, and incident cardiovascular disease: the prevend (prevention of renal and vascular endstage disease) study. Am J Kidney Dis. (2012) 60:80411. doi: 10.1053/j.ajkd.2012.06.017

15. Schmieder RE, Mann JF, Schumacher H, Gao P, Mancia G, Weber MA, et al. Changes in albuminuria predict mortality and morbidity in patients with vascular disease. J Am Soc Nephrol. (2011) 22:135364. doi: 10.1681/ASN.2010091001

16. Danziger J. Importance of low-grade albuminuria. Mayo Clin Proc. (2008) 83:806-12. eng. doi: $10.4065 / 83.7 .806$

17. Remuzzi G, Weening JJ. Albuminuria as early test for vascular disease. Lancet. (2005) 365:556-7. doi: 10.1016/S0140-6736(05)70775-3

18. Ritz E. Albuminuria and vascular damage-the vicious twins. $\mathrm{N} \mathrm{Engl} \mathrm{J} \mathrm{Med.}$ (2003) 348:2349-52. doi: 10.1056/NEJMe030066

19. Gerstein HC, Mann JF, Yi Q, Zinman B, Dinneen SF, Hoogwerf B, et al. Albuminuria and risk of cardiovascular events, death, and heart failure in diabetic and nondiabetic individuals. JAMA. (2001) 286:4216. doi: 10.1001/jama.286.4.421

20. Deen WM, Bridges CR, Brenner BM, Myers BD. Heteroporous model of glomerular size selectivity: application to normal and nephrotic humans. Am J Physiol. (1985) 249:F374-89. doi: 10.1152/ajprenal.1985.249.3.F374

21. Deen WM, Lazzara MJ, Myers BD. Structural determinants of glomerular permeability. Am J Physiol Renal Physiol. (2001) 281:F579-96. doi: 10.1152/ajprenal.2001.281.4.F579

22. Ohlson M, Sorensson J, Haraldsson B. A gel-membrane model of glomerular charge and size selectivity in series. Am J Physiol Renal Physiol. (2001) 280:F396-405. doi: 10.1152/ajprenal.2001.280.3.F396

23. Deen WM, Lazzara MJ. Glomerular filtration of albumin: how small is the sieving coefficient? Kidney Int Suppl. (2004) 92:S63-4. eng. doi: 10.1111/j.1523-1755.2004.09216.x

24. Oberg CM, Groszek JJ, Roy S, Fissell WH, Rippe B. A distributed solute model: an extended two-pore model with application to the glomerular sieving of Ficoll. Am J Physiol Renal Physiol. (2018) 314:F110816. doi: 10.1152 /ajprenal.00066.2017

25. Ohlson M, Sorensson J, Haraldsson B. Glomerular size and charge selectivity in the rat as revealed by fitc-ficoll and albumin. Am J Physiol Renal Physiol. (2000) 279:F84-91. doi: 10.1152/ajprenal.2000.279.1.F84

26. Ohlson M, Sorensson J, Lindstrom K, Blom AM, Fries E, Haraldsson B. Effects of filtration rate on the glomerular barrier and clearance of four differently shaped molecules. Am J Physiol Renal Physiol. (2001) 281:F10313. doi: 10.1152/ajprenal.2001.281.1.F103

27. Sorensson J, Ohlson M, Haraldsson B. A quantitative analysis of the glomerular charge barrier in the rat. Am J Physiol Renal Physiol. (2001) 280:F646-56. eng. doi: 10.1152/ajprenal.2001.280.4.F646

28. Ciarimboli G, Hjalmarsson C, Bokenkamp A, Schurek HJ, Haraldsson B. Dynamic alterations of glomerular charge density in fixed rat kidneys suggest involvement of endothelial cell coat. Am J Physiol Renal Physiol. (2003) 285:F722-30. eng. [pii]. doi: 10.1152/ajprenal.00227.2001

29. Guasch A, Deen WM, Myers BD. Charge selectivity of the glomerular filtration barrier in healthy and nephrotic humans. J Clin Invest. (1993) 92:2274-82. eng. doi: 10.1172/JCI116831

30. Bennett CM, Glassock RJ, Chang RL, Deen WM, Robertson CR, Brenner BM, et al. Permselectivity of the glomerular capillary wall studies of experimental glomerulonephritis in the rat using dextran sulfate. J Clin Invest. (1976) 57:1287-94. doi: 10.1172/JCI108396

31. Chang RL, Deen WM, Robertson CR, Bennett CM, Glassock RJ, Brenner BM, et al. Permselectivity of of the glomerular capillary wall. studies of experimental glomerulonephritis in the rat using neutral dextran. J Clin Invest. (1976) 57:1272-86. doi: 10.1172/JCI108395

32. Haraldsson BS, Johnsson EK, Rippe B. Glomerular Permselectivity Is Dependent on Adequate Serum Concentrations of Orosomucoid. Kidney Int. (1992) 41:310-6. doi: 10.1038/ki.1992.43

33. Tojo A, Endou H. Intrarenal handling of proteins in rats using fractional micropuncture technique. Am J Physiol. (1992) 263:F6016. doi: 10.1152/ajprenal.1992.263.4.F601

34. Bertolatus JA, Hunsicker LG. Glomerular sieving of anionic and neutral bovine albumins in proteinuric rats. Kidney Int. (1985) 28:467-76. doi: $10.1038 /$ ki.1985.153

35. Tencer J, Frick IM, Oquist BW, Alm P, Rippe B. Size-selectivity of the glomerular barrier to high molecular weight proteins: upper size limitations of shunt pathways. Kidney Int. (1998) 53:709-15. doi: 10.1046/j.1523-1755.1998.00797.x

36. Norden AG, Lapsley M, Lee PJ, Pusey CD, Scheinman SJ, Tam FW, et al. Glomerular protein sieving and implications for renal failure in fanconi syndrome. Kidney Int. (2001) 60:1885-92. doi: 10.1046/j.1523-1755.2001.00016.x

37. Russo LM, Sandoval RM, McKee M, Osicka TM, Collins AB, Brown D, et al. The normal kidney filters nephrotic levels of albumin retrieved by proximal tubule cells: retrieval is disrupted in nephrotic states. Kidney Int. (2007) 71:504-13. doi: 10.1038/sj.ki.5002041

38. Wagner MC, Myslinski J, Pratap S, Flores B, Rhodes G, Campos-Bilderback $\mathrm{SB}$, et al. Mechanism of increased clearance of glycated albumin by proximal tubule cells. Am J Physiol Renal Physiol. (2016) 310:F10892. doi: 10.1152/ajprenal.00605.2015

39. Tanner GA. Glomerular sieving coefficient of serum albumin in the rat: a two-photon microscopy study. Am J Physiol Renal Physiol. (2009) 296:F1258-65. doi: 10.1152/ajprenal.90638.2008

40. Schiessl IM, Castrop H. Angiotensin II AT2 receptor activation attenuates AT1 receptor-induced increases in the glomerular filtration of albumin: a multiphoton microscopy study. Am J Physiol Renal Physiol. (2013) 305:F1189-200. doi: 10.1152/ajprenal.00377.2013

41. Peti-Peterdi J, Sipos A. A high-powered view of the filtration barrier. J Am Soc Nephrol. (2010) 21:1835-41. doi: 10.1681/ASN.2010040378

42. Weyer K, Andersen PK, Schmidt K, Mollet G, Antignac C, Birn H, et al. Abolishment of proximal tubule albumin endocytosis does not affect plasma albumin during nephrotic syndrome in mice. Kidney Int. (2018) 93:33542. doi: 10.1016/j.kint.2017.07.024

43. Mori KP, Yokoi H, Kasahara M, Imamaki H, Ishii A, Kuwabara $\mathrm{T}$, et al. Increase of total nephron albumin filtration and reabsorption in diabetic nephropathy. J Am Soc Nephrol. (2017) 28:278-89. doi: 10.1681/ASN.2015101168

44. Tojo A, Kinugasa S. Mechanisms of glomerular albumin filtration and tubular reabsorption. Int $J$ Nephrol. (2012) 2012:481520. doi: 10.1155/2012/481520

45. Chang RS, Robertson CR, Deen WM, Brenner BM. Permselectivity of the glomerular capillary wall to macromolecules. i. theoretical considerations. Biophys J. (1975) 15:861-86. doi: 10.1016/S0006-3495(75)85862-0

46. Edwards A, Daniels BS, Deen WM. Ultrastructural model for size selectivity in glomerular filtration. Am J Physiol. (1999) 276:F892902. doi: 10.1152/ajprenal.1999.276.6.F892

47. Ruggiero A, Villa CH, Bander E, Rey DA, Bergkvist M, Batt CA, et al. Paradoxical glomerular filtration of carbon nanotubes. Proc Natl Acad Sci U S A. (2010) 107:12369-74. doi: 10.1073/pnas.09136 67107 
48. Butt L, Unnersjo-Jess D, Hohne M, Edwards A, Binz-Lotter J, Reilly D, et al. A molecular mechanism explaining albuminuria in kidney disease. Nat Metab. (2020) 2:461-74. doi: 10.1038/s42255-020-0204-y

49. Chang RL, Deen WM, Robertson CR, Brenner BM. Permselectivity of the glomerular capillary wall: iii. restricted transport of polyanions. Kidney Int. (1975) 8:212-8. doi: 10.1038/ki.1975.104

50. Rennke HG, Venkatachalam MA. Glomerular Permeability: IN VIVO Tracer Studies With Polyanionic and Polycationic Ferritins. Kidney Int. (1977) 11:44-53. doi: 10.1038/ki.1977.6

51. Rennke HG, Patel Y, Venkatachalam MA. Glomerular filtration of proteins: clearance of anionic, neutral, and cationic horseradish peroxidase in the rat. Kidney Int. (1978) 13:278-88. doi: 10.1038/ki.1978.41

52. Purtell JN, Pesce AJ, Clyne DH, Miller WC, Pollak VE. Isoelectric point of albumin: effect on renal handling of albumin. Kidney Int. (1979) 16:366-76. doi: 10.1038/ki.1979.139

53. Bhalla G, Deen WM. Effects of charge on osmotic reflection coefficients of macromolecules in fibrous membranes. Biophys J. (2009) 97:1595605. doi: 10.1016/j.bpj.2009.06.038

54. Haraldsson B. Physiological studies of macromolecular transport across capillary walls. studies on continuous capillaries in rat skeletal muscle. Acta Physiol Scand Suppl. (1986) 553:1-40.

55. Hausmann R, Grepl M, Knecht V, Moeller MJ. The glomerular filtration barrier function: new concepts. Curr Opin Nephrol Hypertens. (2012) 21:4419. doi: 10.1097/MNH.0b013e328354a28e

56. Oberg CM, Rippe B. Quantification of the electrostatic properties of the glomerular filtration barrier modeled as a charged fiber matrix separating anionic from neutral ficoll. Am J Physiol Renal Physiol. (2013) 304:F7817. doi: 10.1152/ajprenal.00621.2012

57. Vehaskari VM, Root ER, Germuth FG, Jr., Robson AM. Glomerular charge and urinary protein excretion: effects of systemic and intrarenal polycation infusion in the rat. Kidney Int. (1982) 22:127-35. doi: 10.1038/ki.1982.144

58. Assel E, Neumann KH, Schurek HJ, Sonnenburg C, Stolte H. Glomerular albumin leakage and morphology after neutralization of polyanions. i. albumin clearance and sieving coefficient in the isolated perfused rat kidney. Renal Physiol. (1984) 7:357-64. doi: 10.1159/000172958

59. Hunsicker LG, Shearer TP, Shaffer SJ. Acute reversible proteinuria induced by infusion of the polycation hexadimethrine. Kidney Int. (1981) 20:717. doi: 10.1038/ki.1981.98

60. Gelberg H, Healy L, Whiteley H, Miller LA, Vimr E. In vivo enzymatic removal of alpha 2->6-linked sialic acid from the glomerular filtration barrier results in podocyte charge alteration and glomerular injury. Lab Invest. (1996) 74:907-20.

61. Wijnhoven TJ, Lensen JF, Wismans RG, Lamrani M, Monnens LA, Wevers $\mathrm{RA}$, et al. In vivo degradation of heparan sulfates in the glomerular basement membrane does not result in proteinuria. J Am Soc Nephrol. (2007) 18:82332. doi: 10.1681/ASN.2006070692

62. Jeansson M, Haraldsson B. Glomerular size and charge selectivity in the mouse after exposure to glucosaminoglycan-degrading enzymes. $J$ Am Soc Nephrol. (2003) 14:1756-65. doi: 10.1097/01.ASN.0000072742.02 $714.6 \mathrm{E}$

63. Dane MJ, van den Berg BM, Avramut MC, Faas FG, van der Vlag J, Rops AL, et al. Glomerular endothelial surface layer acts as a barrier against albumin filtration. Am J Pathol. (2013) 182:1532-40. doi: 10.1016/j.ajpath.2013.01.049

64. Daniels BS. Increased albumin permeability in vitro following alterations of glomerular charge is mediated by the cells of the filtration barrier. J Lab Clin Med. (1994) 124:224-30.

65. Goldberg S, Harvey SJ, Cunningham J, Tryggvason K, Miner JH. Glomerular filtration is normal in the absence of both agrin and perlecan-heparan sulfate from the glomerular basement membrane. Nephrol Dial Transplant. (2009) 24:2044-51. doi: 10.1093/ndt/gfn758

66. Chen S, Wassenhove-McCarthy DJ, Yamaguchi Y, Holzman LB, van Kuppevelt TH, Jenniskens GJ, et al. Loss of heparan sulfate glycosaminoglycan assembly in podocytes does not lead to proteinuria. Kidney Int. (2008) 74:289-99. doi: 10.1038/ki.20 08.159

67. Farquhar MG. Editorial: the primary glomerular filtration barrierbasement membrane or epithelial slits? Kidney Int. (1975) 8:197211. doi: $10.1038 / \mathrm{ki} .1975 .103$
68. Lawrence MG, Altenburg MK, Sanford R, Willett JD, Bleasdale B, Ballou $\mathrm{B}$, et al. Permeation of macromolecules into the renal glomerular basement membrane and capture by the tubules. Proc Natl Acad Sci U S A. (2017) 114:2958-2963. doi: 10.1073/pnas.1616457114

69. Caulfield JP, Reid JJ, Farquhar MG. Alterations of the glomerular epithelium in acute aminonucleoside nephrosis. evidence for formation of occluding junctions and epithelial cell detachment. Lab Invest. (1976) 34:43-59.

70. Tryggvason K, Wartiovaara J. Molecular basis of glomerular permselectivity. Curr Opin Nephrol Hypertens. (2001) 10:5439. doi: 10.1097/00041552-200107000-00009

71. Caulfield JP, Farquhar MG. Distribution of annionic sites in glomerular basement membranes: their possible role in filtration and attachment. Proc Natl Acad Sci U S A. (1976) 73:1646-50. doi: 10.1073/pnas.73.5.1646

72. Rada JA, Carlson EC. Electron microscopic histochemical and immunochemical analyses of heparan sulfate proteoglycan distribution in renal glomerular basement membranes. Histol Histopathol. (1991) 6:149-60.

73. Goode NP, Shires M, Aparicio SR, Davison AM. Cationic colloidal gold-a novel marker for the demonstration of glomerular polyanion status in routine renal biopsies. Nephrol Dial Transplant. (1991) 6:92330. doi: $10.1093 / \mathrm{ndt} / 6.12 .923$

74. Bohrer MP, Baylis C, Humes HD, Glassock RJ, Robertson CR, Brenner BM. Permselectivity of the glomerular capillary wall. facilitated filtration of circulating polycations. J Clin Invest. (1978) 61:72-8. doi: 10.1172/JCI108927

75. Kopp JB, Anders HJ, Susztak K, Podesta MA, Remuzzi G, Hildebrandt F, et al. Podocytopathies. Nat Rev Dis Primers. (2020) 6:68. doi: 10.1038/s41572-020-0196-7

76. Kanwar YS, Rosenzweig LJ. Clogging of the glomerular basement membrane. J Cell Biol. (1982) 93:489-94. doi: 10.1083/jcb.93.2.489

77. Smithies $O$. Why the kidney glomerulus does not clog: a gel permeation/diffusion hypothesis of renal function. Proc Natl Acad Sci US A. (2003) 100:4108-13. doi: 10.1073/pnas.0730776100

78. Inoue $\mathrm{K}$, Ishibe $\mathrm{S}$. Podocyte endocytosis in the regulation of the glomerular filtration barrier. Am J Physiol Renal Physiol. (2015) 309:F398405. doi: 10.1152/ajprenal.00136.2015

79. Gburek J, Konopska B, Golab K. Renal handling of albuminfrom early findings to current concepts. Int J Mol Sci. (2021) 22 (11). doi: 10.3390/ijms22115809

80. Russell PS, Hong J, Windsor JA, Itkin M, Phillips ARJ. Renal lymphatics: anatomy, physiology, and clinical implications. Front Physiol. (2019) 10:251. doi: 10.3389/fphys.2019.00251

81. Ryan GB, Karnovsky MJ. Distribution of endogenous albumin in the rat glomerulus: role of hemodynamic factors in glomerular barrier function. Kidney Int. (1976) 9:36-45. doi: 10.1038/ki.1976.5

82. Koshy V, Avasthi PS. The anionic sites at luminal surface of peritubular capillaries in rats. Kidney Int. (1987) 31:52-8. doi: 10.1038/ki.1987.8

83. Li L, Liu Q, Shang T, Song W, Xu D, Allen TD, et al. Aberrant activation of notch1 signaling in glomerular endothelium induces albuminuria. Circ Res. (2021) 128:602-18. doi: 10.1161/CIRCRESAHA.120.316970

84. Haraldsson B, Nystrom J, Deen WM. Properties of the glomerular barrier and mechanisms of proteinuria. Physiol Rev. (2008) 88:451-87. eng. doi: 10.1152/physrev.00055.2006

85. Deen WM. Cellular contributions to glomerular size-selectivity. Kidney Int. (2006) 69:1295-7. eng. doi: 10.1038/sj.ki.5000322

86. Bhalla G, Deen WM. Effects of charge on osmotic reflection coefficients of macromolecules in porous membranes. J Colloid Interface Sci. (2009) 333:363-72. doi: 10.1016/j.jcis.2009.01.019

87. Ebefors K, Lassen E, Anandakrishnan N, Azeloglu EU, Daehn IS. Modeling the glomerular filtration barrier and intercellular crosstalk. Frontiers in Physiology. (2021) 12:689083. doi: 10.3389/fphys.2021.689083

88. Haraldsson B, Nystrom J. The glomerular endothelium: new insights on function and structure. Curr Opin Nephrol Hypertens. (2012) 21:25863. doi: 10.1097/MNH.0b013e3283522e7a

89. Avasthi PS, Koshy V. Glomerular endothelial glycocalyx. Contrib Nephrol. (1988) 68:104-13. eng. doi: 10.1159/000416500

90. Scott RP, Quaggin SE. Review series: the cell biology of renal filtration. J Cell Biol. (2015) 209:199-210. doi: 10.1083/jcb.201410017

91. Satchell S. The role of the glomerular endothelium in albumin handling. Nat Rev Nephrol. (2013) 9:717-25. doi: 10.1038/nrneph.2013.197 
92. Camici M. Renal glomerular permselectivity and vascular endothelium. Biomed Pharmacotherap. (2005) 59:30-7. doi: 10.1016/j.biopha.2004.06.003

93. Haraldsson B, Sörensson J. Why do we not all have proteinuria? an update of our current understanding of the glomerular barrier. News Physiol Sci. (2004) 19:7-10. doi: 10.1152/nips.01461.2003

94. Ballermann BJ. Contribution of the endothelium to the glomerular permselectivity barrier in health and disease. Nephron Physiol. (2007) 106:p19-25. eng. doi: 10.1159/000101796

95. Singh A, Satchell SC, Neal CR, McKenzie EA, Tooke JE, Mathieson PW. Glomerular endothelial glycocalyx constitutes a barrier to protein permeability. J Am Soc Nephrol. (2007) 18:2885-93. doi: 10.1681/ASN.2007010119

96. Rostgaard J, Qvortrup K. Electron microscopic demonstrations of filamentous molecular sieve plugs in capillary fenestrae. Microvasc Res. (1997) 53:1-13. doi: 10.1006/mvre.1996.1987

97. Stan RV, Kubitza M, Palade GE. PV-1 is a component of the fenestral and stomatal diaphragms in fenestrated endothelia. Proc Natl Acad Sci U S A. (1999) 96:13203-7. doi: 10.1073/pnas.96.23.13203

98. Levick JR, Smaje LH. An analysis of the permeability of a fenestra. Microvasc Res. (1987) 33:233-56. doi: 10.1016/0026-2862(87)90020-3

99. Avasthi PS, Evan AP, Hay D. Glomerular endothelial cells in uranyl nitrate-induced acute renal failure in rats. J Clin Invest. (1980) 65:1217. doi: $10.1172 /$ JCI109641

100. Avasthi PS, Evan AP, Huser JW, Luft FC. Effect of gentamicin on glomerular ultrastructure. J Lab Clin Med. (1981) 98:444-54. Available online at: https:// pubmed.ncbi.nlm.nih.gov/7264439/

101. Evan AP, Luft FC. Effect of alloxan-induced diabetes on the glomerular filtration barrier of the rat. Renal Physiol. (1980) 3:257-64. doi: 10.1159/000172769

102. Toyoda M, Najafian B, Kim Y, Caramori ML, Mauer M. Podocyte detachment and reduced glomerular capillary endothelial fenestration in human type 1 diabetic nephropathy. Diabetes. (2007) 56:215560. doi: $10.2337 / \mathrm{db} 07-0019$

103. Lafayette RA, Druzin M, Sibley R, Derby G, Malik T, Huie P, et al. Nature of glomerular dysfunction in pre-eclampsia. Kidney Int. (1998) 54:1240-9. eng. doi: 10.1046/j.1523-1755.1998.00097.x

104. Renkin EM. Multiple pathways of capillary permeability. Circ Res. (1977) 41:735-43. doi: 10.1161/01.RES.41.6.735

105. Luft JH. Fine structures of capillary and endocapillary layer as revealed by ruthenium red. Fed Proc. (1966) 25:1773-83.

106. Avasthi PS, Koshy V. The anionic matrix at the rat glomerular endothelial surface. Anatomic Rec. (1988) 220:258-66. doi: 10.1002/ar.1092200306

107. Hjalmarsson C, Johansson BR, Haraldsson B. Electron microscopic evaluation of the endothelial surface layer of glomerular capillaries. Microvasc Res. (2004) 67:9-17. doi: 10.1016/j.mvr.2003.10.001

108. Hegermann J, Lunsdorf $H$, Ochs $M$, Haller $H$. Visualization of the glomerular endothelial glycocalyx by electron microscopy using cationic colloidal thorium dioxide. Histochemistr Cell Biol. (2016) 145:41-51. doi: 10.1007/s00418-015-1378-3

109. Squire JM, Chew M, Nneji G, Neal C, Barry J, Michel C. Quasiperiodic substructure in the microvessel endothelial glycocalyx: a possible explanation for molecular filtering? J Struct Biol. (2001) 136:23955. doi: 10.1006/jsbi.2002.4441

110. Fan J, Sun Y, Xia Y, Tarbell JM, Fu BM. Endothelial surface glycocalyx (ESG) components and ultra-structure revealed by stochastic optical reconstruction microscopy (STORM). Biorheology. (2019) 56:77-88. doi: 10.3233/BIR-180204

111. Xia Y, Fu BM. Investigation of endothelial surface glycocalyx components and ultrastructure by single molecule localization microscopy: stochastic optical reconstruction microscopy (STORM). Yale J Biol Med. (2018) 91:25766.

112. Vink H, Duling BR. Capillary endothelial surface layer selectively reduces plasma solute distribution volume. Am J Physiol Heart Circ Physiol. (2000) 278:H285-9. doi: 10.1152/ajpheart.2000.278.1.H285

113. Henry CB, Duling BR. Permeation of the luminal capillary glycocalyx is determined by hyaluronan. Am J Physiol. (1999) 277 (2 Pt 2):H508-14. eng. doi: 10.1152/ajpheart.1999.277.2.H508
114. Jeansson M, Haraldsson B. Morphological and functional evidence for an important role of the endothelial cell glycocalyx in the glomerular barrier. Am J Physiol Renal Physiol. (2006) 290:F111-6. doi: 10.1152/ajprenal.00173.2005

115. Friden V, Oveland E, Tenstad O, Ebefors K, Nystrom J, Nilsson UA, et al. The glomerular endothelial cell coat is essential for glomerular filtration. Kidney Int. (2011) 79:1322-30. doi: 10.1038/ki.2011.58

116. Hahn RG, Patel V, Dull RO. Human glycocalyx shedding: systematic review and critical appraisal. Acta Anaesthesiol Scand. (2021) 65:590606. doi: 10.1111/aas.13797

117. Moore KH, Murphy HA, George EM. The glycocalyx: a central regulator of vascular function. Am J Physiol Regulat Integrat Comparat Physiol. (2021) 320:R508-18. doi: 10.1152/ajpregu.00340.2020

118. Pries AR, Secomb TW, Gaehtgens P. The endothelial surface layer. Pflugers Arch. (2000) 440:653-6. doi: 10.1007/s004240000307

119. Simpson MA, de la Motte C, Sherman LS, Weigel PH. Advances in hyaluronan biology: signaling, regulation, and disease mechanisms. Int J Cell Biol. (2015) 2015:690572. doi: 10.1155/2015/690572

120. Sarrazin S, Lamanna WC, Esko JD. Heparan sulfate proteoglycans. Cold Spring Harb Perspect Biol. (2011) 3:4952. doi: 10.1101/cshperspect.a004952

121. Pomin VH, Vignovich WP, Gonzales AV, Vasconcelos AA, Mulloy B. Galactosaminoglycans: medical applications and drawbacks. Molecules. (2019) 24:15. doi: 10.3390/molecules 24152803

122. Funderburgh JL. Keratan sulfate: structure, biosynthesis, and function. Glycobiology. (2000) 10:951-8. doi: 10.1093/glycob/10.10.951

123. Li JP. Glucuronyl C5-epimerase an enzyme converting glucuronic acid to iduronic acid in heparan sulfate/heparin biosynthesis. Progr Mol Biol Transl Sci. (2010) 93:59-78. doi: 10.1016/S1877-1173(10)93004-4

124. Fransson LA, Belting M, Cheng F, Jonsson M, Mani K, Sandgren S. Novel aspects of glypican glycobiology. Cell Mol Life Sci. CMLS. (2004) 61:101624. doi: $10.1007 / \mathrm{s} 00018-004-3445-0$

125. Ihrcke NS, Platt JL. Shedding of heparan sulfate proteoglycan by stimulated endothelial cells: evidence for proteolysis of cell-surface molecules. J Cell Physiol. (1996) 168:625-37. doi: 10.1002/(SICI) 1097-4652(199609)168:3<625::AID-JCP15>3.0.CO;2-Y

126. Becker BF, Jacob M, Leipert S, Salmon AH, Chappell D. Degradation of the endothelial glycocalyx in clinical settings: searching for the sheddases. $\mathrm{Br} \mathrm{J}$ Clin Pharmacol. (2015) 80:389-402. doi: 10.1111/bcp.12629

127. Reine TM, Lanzalaco F, Kristiansen O, Enget AR, Satchell S, Jenssen TG, et al. Matrix metalloproteinase-9 mediated shedding of syndecan-4 in glomerular endothelial cells. Microcirculation. (2019) 31:E12534. doi: 10.1111/micc.12534

128. Weigel PH. Hyaluronan synthase: the mechanism of initiation at the reducing end and a pendulum model for polysaccharide translocation to the cell exterior. Int J Cell Biol. (2015) 2015:367579. doi: 10.1155/2015/367579

129. Wang G, Kostidis S, Tiemeier GL, Sol W, de Vries MR, Giera M, et al. Shear stress regulation of endothelial glycocalyx structure is determined by glucobiosynthesis. Arterioscler Thromb Vascul Biol. (2020) 40:35064. doi: 10.1161/ATVBAHA.119.313399

130. Hascall VC, Wang A, Tammi M, Oikari S, Tammi R, Passi A, et al. The dynamic metabolism of hyaluronan regulates the cytosolic concentration of UDP-GlcNAc. Matrix Biol J Int Soc Matrix Biol. (2014) 35:147. doi: 10.1016/j.matbio.2014.01.014

131. Kobayashi T, Chanmee T, Itano N. Hyaluronan: metabolism and function. Biomolecules. (2020) 10:525. doi: 10.3390/biom10111525

132. Viola M, Karousou E, D’Angelo ML, Caon I, De Luca G, Passi A, et al. Regulated hyaluronan synthesis by vascular cells. Int J Cell Biol. (2015) 2015:208303. doi: $10.1155 / 2015 / 208303$

133. Nandi A, Estess P, Siegelman MH. Hyaluronan anchoring and regulation on the surface of vascular endothelial cells is mediated through the functionally active form of CD44. J Biol Chem. (2000) 275:1493948. doi: 10.1074/jbc.275.20.14939

134. Queisser KA, Mellema RA, Petrey AC. Hyaluronan and its receptors as regulatory molecules of the endothelial interface. J Histochem Cytochem. (2021) 69:25-34. doi: 10.1369/0022155420954296

135. Jensen PV, Larsson LI. Actin microdomains on endothelial cells: association with $\mathrm{cd} 44$, erm proteins, and signaling molecules during 
quiescence and wound healing. Histochemistr Cell Biol. (2004) 121:361-9. doi: 10.1007/s00418-004-0648-2

136. Singleton PA. Hyaluronan regulation of endothelial barrier function in cancer. Adv Cancer Res. (2014) 123:191209. doi: 10.1016/B978-0-12-800092-2.00007-1

137. Singleton PA, Dudek SM, Ma SF, Garcia JG. Transactivation of sphingosine 1-phosphate receptors is essential for vascular barrier regulation. novel role for hyaluronan and cd44 receptor family. J Biol Chem. (2006) 281:3438193. doi: $10.1074 /$ jbc.M603680200

138. Singleton PA, Bourguignon LY. CD44 interaction with ankyrin and ip3 receptor in lipid rafts promotes hyaluronan-mediated $\mathrm{Ca} 2+$ signaling leading to nitric oxide production and endothelial cell adhesion and proliferation. Exp Cell Res. (2004) 295:10218. doi: 10.1016/j.yexcr.2003.12.025

139. Maroski J, Vorderwulbecke BJ, Fiedorowicz K, Da Silva-Azevedo L, Siegel G, Marki A, et al. Shear stress increases endothelial hyaluronan synthase 2 and hyaluronan synthesis especially in regard to an atheroprotective flow profile. Exp Physiol. (2011) 96:977-86. doi: 10.1113/expphysiol.2010.056051

140. Mochizuki S, Vink H, Hiramatsu O, Kajita T, Shigeto F, Spaan JA, et al. Role of hyaluronic acid glycosaminoglycans in shear-induced endotheliumderived nitric oxide release. Am J Physiol Heart Circ Physiol. (2003) 285:H722-6. doi: 10.1152/ajpheart.00691.2002

141. Yamaguchi Y, Yamamoto H, Tobisawa Y, Irie F. TMEM2: a missing link in hyaluronan catabolism identified? Matrix Biol J Int Soc Matrix Biol. (2019) 78:139-46. doi: 10.1016/j.matbio.2018.03.020

142. Weigel PH. Systemic glycosaminoglycan clearance by hare/stabilin-2 activates intracellular signaling. Cells. (2020) 9:66. doi: 10.3390/cells9112366

143. Yoshida H, Nagaoka A, Kusaka-Kikushima A, Tobiishi M, Kawabata K, Sayo T, et al. KIAA1199, a deafness gene of unknown function, is a new hyaluronan binding protein involved in hyaluronan depolymerization. Proc Natl Acad Sci U S A. (2013) 110:5612-7. doi: 10.1073/pnas.1215432110

144. De Angelis JE, Lagendijk AK, Chen H, Tromp A, Bower NI, Tunny KA, et al. Tmem2 regulates embryonic vegf signaling by controlling hyaluronic acid turnover. Development Cell. (2017) 40:123-136. doi: 10.1016/j.devcel.2017.02.005

145. Hunger J, Bernecker A, Bakker HJ, Bonn M, Richter RP. Hydration dynamics of hyaluronan and dextran. Biophys J. (2012) 103:L102. doi: 10.1016/j.bpj.2012.05.028

146. Gouverneur M, Spaan JA, Pannekoek H, Fontijn RD, Vink H. Fluid shear stress stimulates incorporation of hyaluronan into endothelial cell glycocalyx. Am J Physiol Heart Circ Physiol. (2006) 290:H4582. doi: 10.1152/ajpheart.00592.2005

147. Kadoya H, Yu N, Schiessl IM, Riquier-Brison A, Gyarmati G, Desposito D, et al. Essential role and therapeutic targeting of the glomerular endothelial glycocalyx in lupus nephritis. JCI Insight. (2020) 5 (19). doi: $10.1172 /$ jci.insight. 131252

148. van den Berg BM, Wang G, Boels MGS, Avramut MC, Jansen E, Sol W, et al. Glomerular function and structural integrity depend on hyaluronan synthesis by glomerular endothelium. J Am Soc Nephrol. (2019) 30:18861897. doi: 10.1681/ASN.2019020192

149. Dogne S, Rath G, Jouret F, Caron N, Dessy C, Flamion B. Hyaluronidase 1 deficiency preserves endothelial function and glycocalyx integrity in early streptozotocin-induced diabetes. Diabetes. (2016) 65:2742-53. doi: $10.2337 / \mathrm{db} 15-1662$

150. Nieuwdorp M, Holleman F, de Groot E, Vink H, Gort J, Kontush A, et al. Perturbation of hyaluronan metabolism predisposes patients with type 1 diabetes mellitus to atherosclerosis. Diabetologia. (2007) 50:1288-93. eng. doi: 10.1007/s00125-007-0666-4

151. Nieuwdorp M, Mooij HL, Kroon J, Atasever B, Spaan JA, Ince $\mathrm{C}$, et al. Endothelial glycocalyx damage coincides with microalbuminuria in type 1 diabetes. Diabetes. (2006) 55:112732. doi: $10.2337 /$ diabetes.55.04.06.db05-1619

152. Siegel G, Malmsten M, Ermilov E. Anionic biopolyelectrolytes of the syndecan/perlecan superfamily: physicochemical properties and medical significance. Adv Colloid Interface Sci. (2014) 205:275-318. doi: 10.1016/j.cis.2014. 01.009
153. Pataki CA, Couchman JR, Brabek J. Wnt signaling cascades and the roles of syndecan proteoglycans. J Histochem Cytochem. (2015) 63:46580. doi: $10.1369 / 0022155415586961$

154. Elfenbein A, Simons M. Syndecan-4 signaling at a glance. J Cell Sci. (2013) 126 (Pt 17):3799-804. doi: 10.1242/jcs. 124636

155. Essner JJ, Chen E, Ekker SC. Syndecan-2. Int J Biochemistr Cell Biol. (2006) 38:152-6. doi: 10.1016/j.biocel.2005.08.012

156. De Rossi G, Whiteford JR. Syndecans in angiogenesis and endothelial cell biology. Biochem Soc Trans. (2014) 42:1643-6. doi: 10.1042/BST20140232

157. Beauvais DM, Ell BJ, McWhorter AR, Rapraeger AC. Syndecan-1 regulates alphavbeta3 and alphavbeta5 integrin activation during angiogenesis and is blocked by synstatin, a novel peptide inhibitor. J Exp Med. (2009) 206:691705. doi: $10.1084 /$ jem. 20081278

158. Vuong TT, Reine TM, Sudworth A, Jenssen TG, Kolset SO. Syndecan-4 Is a major syndecan in primary human endothelial cells in vitro, modulated by inflammatory stimuli and involved in wound healing. J Histochem Cytochem. (2015) 63:280-92. doi: 10.1369/0022155415568995

159. Volokhina EB, Feitz WJC, Elders LM, van der Velden T, van de Kar N, van den Heuvel L. Shiga toxin selectively upregulates expression of syndecan4 and adhesion molecule icam-1 in human glomerular microvascular endothelium. Toxins. (2020) 12:435. doi: 10.3390/toxins12070435

160. Gopal S. Syndecans in Inflammation at a Glance. Front Immunol. (2020) 11:227. doi: 10.3389/fimmu.2020.00227

161. Rapraeger AC, Ell BJ, Roy M, Li X, Morrison OR, Thomas GM, et al. Vascular endothelial-cadherin stimulates syndecan-1-coupled insulin-like growth factor-1 receptor and cross-talk between alphavbeta3 integrin and vascular endothelial growth factor receptor 2 at the onset of endothelial cell dissemination during angiogenesis. FEBS J. (2013) 280:2194206. doi: $10.1111 /$ febs.12134

162. Jiang XZ, Luo KH, Ventikos Y. Principal mode of syndecan-4 mechanotransduction for the endothelial glycocalyx is a scissor-like dimer motion. Acta Physiologica. (2020) 228:E13376. doi: 10.1111/apha.13376

163. Ebong EE, Lopez-Quintero SV, Rizzo V, Spray DC, Tarbell JM. Shearinduced endothelial nos activation and remodeling via heparan sulfate, glypican-1, and syndecan-1. Integr Biol (Camb). (2014) 6:338-47. doi: 10.1039/C3IB40199E

164. Bjornson A, Moses J, Ingemansson A, Haraldsson B, Sorensson J. Primary human glomerular endothelial cells produce proteoglycans, and puromycin affects their posttranslational modification. Am J Physiol Renal Physiol. (2005) 288:F748-56. doi: 10.1152/ajprenal.00202.2004

165. Muller-Deile J, Gellrich F, Schenk H, Schroder P, Nystrom J, Lorenzen J, et al. Overexpression of TGF-beta inducible microrna-143 in zebrafish leads to impairment of the glomerular filtration barrier by targeting proteoglycans. Cell Physiol Biochem. (2016) 40:819-30. doi: 10.1159/000453142

166. Subramanian SV, Fitzgerald ML, Bernfield M. Regulated shedding of syndecan-1 and -4 ectodomains by thrombin and growth factor receptor activation. J Biol Chem. (1997) 272:14713-20. doi: 10.1074/jbc.272.23.14713

167. Ramnath RD, Butler MJ, Newman G, Desideri S, Russell A, Lay AC, et al. Blocking matrix metalloproteinase-mediated syndecan-4 shedding restores the endothelial glycocalyx and glomerular filtration barrier function in early diabetic kidney disease. Kidney Int. (2020) 97:95165. doi: 10.1016/j.kint.2019.09.035

168. Slater SC, Ramnath RD, Uttridge K, Saleem MA, Cahill PA, Mathieson $\mathrm{PW}$, et al. Chronic exposure to laminar shear stress induces kruppellike factor 2 in glomerular endothelial cells and modulates interactions with co-cultured podocytes. Int J Biochem Cell Biol. (2012) 44:148290. doi: 10.1016/j.biocel.2012.05.020

169. Schmidt A, Echtermeyer F, Alozie A, Brands K, Buddecke E. Plasminand thrombin-accelerated shedding of syndecan-4 ectodomain generates cleavage sites at Lys (114)-Arg (115) and Lys (129)-Val (130) bonds. J Biol Chem. (2005) 280:34441-6. doi: 10.1074/jbc.M501903200

170. Duni A, Liakopoulos V, Koutlas V, Pappas C, Mitsis M, Dounousi E. The endothelial glycocalyx as a target of ischemia and reperfusion injury in kidney transplantation-where have we gone so far? Int J Mol Sci. (2021) 22 (4). doi: 10.3390/ijms 22042157

171. Weissgerber TL, Garcia-Valencia O, Milic NM, Codsi E, Cubro H, Nath MC, et al. Early onset preeclampsia is associated with glycocalyx 
degradation and reduced microvascular perfusion. J Am Heart Assoc. (2019) 8:E010647. doi: 10.1161/JAHA.118.010647

172. Butler MJ, Ramnath R, Kadoya H, Desposito D, Riquier-Brison A, Ferguson $\mathrm{JK}$, et al. Aldosterone induces albuminuria via matrix metalloproteinasedependent damage of the endothelial glycocalyx. Kidney Int. (2019) 95:94107. doi: 10.1016/j.kint.2018.08.024

173. Ramnath R, Foster RR, Qiu Y, Cope G, Butler MJ, Salmon AH, et al. Matrix metalloproteinase 9-mediated shedding of syndecan 4 in response to tumor necrosis factor alpha: a contributor to endothelial cell glycocalyx dysfunction. FASEB J. (2014) 28:4686-99. doi: 10.1096/fj.14-252221

174. Lepedda AJ, Nieddu G, Piperigkou Z, Kyriakopoulou K, Karamanos $\mathrm{N}$, Formato M. Circulating heparan sulfate proteoglycans as biomarkers in health and disease. Semin Thromb Hemost. (2021) 47:295-307. doi: 10.1055/s-0041-1725063

175. Adembri C, Sgambati E, Vitali L, Selmi V, Margheri M, Tani A, et al. Sepsis induces albuminuria and alterations in the glomerular filtration barrier: a morphofunctional study in the rat. Crit Care. (2011) 15:R277. doi: 10.1186/cc10559

176. Savery MD, Jiang JX, Park PW, Damiano ER. The endothelial glycocalyx in syndecan-1 deficient mice. Microvasc Res. (2013) 87:83-91. doi: 10.1016/j.mvr.2013.02.001

177. Zeng Y, Liu XH, Tarbell J, Fu B. Sphingosine 1-phosphate induced synthesis of glycocalyx on endothelial cells. Exp Cell Res. (2015) 339:905. doi: 10.1016/j.yexcr.2015.08.013

178. Yatomi Y, Ohmori T, Rile G, Kazama F, Okamoto H, Sano T, et al. Sphingosine 1-phosphate as a major bioactive lysophospholipid that is released from platelets and interacts with endothelial cells. Blood. (2000) 96:3431-8. doi: 10.1182/blood.V96.10.3431

179. Aldecoa C, Llau JV, Nuvials X, Artigas A. Role of albumin in the preservation of endothelial glycocalyx integrity and the microcirculation: a review. Ann Intensive Care. (2020) 10:85. doi: 10.1186/s13613-020-00697-1

180. Padberg JS, Wiesinger A, di Marco GS, Reuter S, Grabner A, Kentrup D, et al. Damage of the endothelial glycocalyx in chronic kidney disease. Atherosclerosis. (2014) 234:33543. doi: 10.1016/j.atherosclerosis.2014.03.016

181. Filmus J, Capurro M, Rast J. Glypicans. Genome Biol. (2008) 9:224. doi: 10.1186/gb-2008-9-5-224

182. Gengrinovitch S, Berman B, David G, Witte L, Neufeld G, Ron D. Glypican-1 Is a vegf 165 binding proteoglycan that acts as an extracellular chaperone for vegf165. J Biol Chem. (1999) 274:10816-22. doi: 10.1074/jbc.274.16.10816

183. Qiao D, Meyer K, Mundhenke C, Drew SA, Friedl A. Heparan sulfate proteoglycans as regulators of fibroblast growth factor-2 signaling in brain endothelial cells. specific role for glypican-1 in glioma angiogenesis. J Biol Chem. (2003) 278:16045-53. doi: 10.1074/jbc.M211259200

184. Zeng Y, Waters M, Andrews A, Honarmandi P, Ebong EE, Rizzo V, et al. Fluid shear stress induces the clustering of heparan sulfate via mobility of glypican-1 in lipid rafts. Am J Physiol Heart Circ Physiol. (2013) 305:H81120. doi: 10.1152/ajpheart.00764.2012

185. Bartosch AMW, Mathews R, Tarbell JM. Endothelial glycocalyx-mediated nitric oxide production in response to selective AFM pulling. Biophys J. (2017) 113:101-108. doi: 10.1016/j.bpj.2017.05.033

186. Bartosch AMW, Mathews R, Mahmoud MM, Cancel LM, Haq ZS, Tarbell JM. Heparan sulfate proteoglycan glypican-1 and PECAM-1 cooperate in shear-induced endothelial nitric oxide production. Sci Rep. (2021) 11:11386. doi: 10.1038/s41598-021-90941-w

187. Mahmoud M, Mayer M, Cancel LM, Bartosch AM, Mathews R, Tarbell JM. The glycocalyx core protein glypican 1 protects vessel wall endothelial cells from stiffness-mediated dysfunction and disease. Cardiovascular Research. (2021) 117:1592-1605. doi: 10.1093/cvr/cvaa201

188. Mani K, Jonsson M, Edgren G, Belting M, Fransson LA. A novel role for nitric oxide in the endogenous degradation of heparan sulfate during recycling of glypican-1 in vascular endothelial cells. Glycobiology. (2000) 10:577-86. doi: 10.1093/glycob/10.6.577

189. Iozzo RV, Schaefer L. Proteoglycan form and function: a comprehensive nomenclature of proteoglycans. Matrix Biol J Int Soc Matrix Biol. (2015) 42:11-55. doi: 10.1016/j.matbio.2015. 02.003
190. Nijenhuis N, Mizuno D, Spaan JA, Schmidt CF. Viscoelastic response of a model endothelial glycocalyx. Phys Biol. (2009) 6:025014. doi: 10.1088/1478-3975/6/2/025014

191. Morita H, Takeuchi T, Suzuki S, Maeda K, Yamada K, Eguchi G, et al. Aortic endothelial cells synthesize a large chondroitin sulphate proteoglycan capable of binding to hyaluronate. Biochem J. (1990) 265:618. doi: $10.1042 /$ bj2650061

192. Cattaruzza S, Schiappacassi M, Ljungberg-Rose A, Spessotto P, Perissinotto D, Morgelin M, et al. Distribution of PG-M/versican variants in human tissues and de novo expression of isoform $\mathrm{v} 3$ upon endothelial cell activation, migration, and neoangiogenesis in vitro. J Biol Chem. (2002) 277:4762635. doi: $10.1074 /$ jbc.M206521200

193. Koch CD, Lee CM, Apte SS. Aggrecan in cardiovascular development and disease. J Histochem Cytochem. (2020) 68:777-795. doi: 10.1369/0022155420952902

194. Aspberg A, Adam S, Kostka G, Timpl R, Heinegard D. Fibulin-1 Is a ligand for the c-type lectin domains of aggrecan and versican. J Biol Chem. (1999) 274:20444-9. doi: 10.1074/jbc.274.29.20444

195. Foster RR, Armstrong L, Baker S, Wong DW, Wylie EC, Ramnath R, et al. Glycosaminoglycan regulation by vegfa and vegfc of the glomerular microvascular endothelial cell glycocalyx in vitro. Am J Pathol. (2013) 183:604-16. doi: 10.1016/j.ajpath.2013.04.019

196. Jeansson M, Bjorck K, Tenstad O, Haraldsson B. adriamycin alters glomerular endothelium to induce proteinuria. J Am Soc Nephrol. (2009) 20:114-22. eng. doi: 10.1681/ASN.2007111205

197. Jeansson M, Granqvist AB, Nystrom JS, Haraldsson B. Functional and molecular alterations of the glomerular barrier in long-term diabetes in mice. Diabetologia. (2006) 49:2200-9. doi: 10.1007/s00125-006-0319-z

198. Melrose J. Perlecan, a modular instructive proteoglycan with diverse functional properties. Int J Biochemistr Cell Biol. (2020) 128:105849. doi: 10.1016/j.biocel.2020.105849

199. Douglass S, Goyal A, Iozzo RV. The role of perlecan and endorepellin in the control of tumor angiogenesis and endothelial cell autophagy. Connect Tissue Res. (2015) 56:381-91. doi: 10.3109/03008207.2015.1045297

200. Vischer P, Feitsma K, Schon P, Volker W. Perlecan is responsible for thrombospondin 1 binding on the cell surface of cultured porcine endothelial cells. Eur J Cell Biol. (1997) 73:332-43.

201. Nakamura K, Ikeuchi T, Nara K, Rhodes CS, Zhang P, Chiba Y, et al. Perlecan regulates pericyte dynamics in the maintenance and repair of the blood-brain barrier. J Cell Biol. (2019) 218:3506-3525. doi: 10.1083/jcb.201807178

202. Akbas M, Koyuncu FM, Artunc-Ulkumen B, Taneli F, Ozdemir H. Maternal serum perlecan levels in women with preeclampsia. Hypertens Pregn. (2020) 39:70-76. doi: 10.1080/10641955.2019.1711390

203. Matsushima N, Miyashita H, Kretsinger RH. Sequence features, structure, ligand interaction, and diseases in small leucine rich repeat proteoglycans. $J$ Cell Commun Signal. (2021) 16:4. doi: 10.1007/s12079-021-00616-4

204. Moss J, Shore I, Woodrow D. An ultrastructural study of the colocalization of biglycan and decorin with aa amyloid fibrils in human renal glomeruli. Amyloid. (1998) 5:43-8. doi: 10.3109/13506129809007289

205. Schaefer L, Grone HJ, Raslik I, Robenek H, Ugorcakova J, Budny S, et al. Small proteoglycans of normal adult human kidney: distinct expression patterns of decorin, biglycan, fibromodulin, and lumican. Kidney Int. (2000) 58:1557-68. doi: 10.1046/j.1523-1755.2000.00317.x

206. Jarvelainen H, Sainio A, Wight TN. Pivotal role for decorin in angiogenesis. Matrix Biol J Int Soc Matrix Biol. (2015) 43:15-26. doi: 10.1016/j.matbio.2015.01.023

207. Kinsella MG, Tsoi CK, Jarvelainen HT, Wight TN. Selective expression and processing of biglycan during migration of bovine aortic endothelial cells. the role of endogenous basic fibroblast growth factor. J Biol Chem. (1997) 272:318-25. doi: 10.1074/jbc.272.1.318

208. Khramova A, Boi R, Friden V, Granqvist AB, Nilsson U, Tenstad O, et al. Proteoglycans contribute to the functional integrity of the glomerular endothelial cell surface layer and are regulated in diabetic kidney disease. Sci Rep. (2021) 11:8487. doi: 10.1038/s41598-021-87753-3

209. Gubbiotti MA, Buraschi S, Kapoor A, Iozzo RV. Proteoglycan signaling in tumor angiogenesis and endothelial cell autophagy. Semin Cancer Biol. (2020) 62:1-8. doi: 10.1016/j.semcancer.2019.05.003 
210. Sarrazin S, Lyon M, Deakin JA, Guerrini M, Lassalle P, Delehedde M, et al. Characterization and binding activity of the chondroitin/dermatan sulfate chain from endocan, a soluble endothelial proteoglycan. Glycobiology. (2010) 20:1380-8. doi: 10.1093/glycob/cwq100

211. Oktar SF, Guney I, Eren SA, Oktar L, Kosar K, Buyukterzi Z, et al. Serum endocan levels, carotid intima-media thickness and microalbuminuria in patients with newly diagnosed hypertension. Clinic Experiment Hyperten. (2019) 41:787-794. doi: 10.1080/10641963.2019.1652632

212. Kolset SO, Tveit H. Serglycin-Structure and Biology. Cell Mol Life Sci: CMLS. (2008) 65:1073-85. doi: 10.1007/s00018-007-7455-6

213. Korpetinou A, Skandalis SS, Labropoulou VT, Smirlaki G, Noulas A, Karamanos NK, et al. Serglycin: at the crossroad of inflammation and malignancy. Front Oncol. (2014) 3:327. doi: 10.3389/fonc.2013.00327

214. Meen AJ, Oynebraten I, Reine TM, Duelli A, Svennevig K, Pejler G, et al. Serglycin Is a Major Proteoglycan in polarized human endothelial cells and is implicated in the secretion of the chemokine GROalpha/CXCL1. J Biol Chem. (2011) 286:2636-47. doi: 10.1074/jbc.M110.151944

215. Herzog BH, Fu J, Xia L. Mucin-Type O-glycosylation is critical for vascular integrity. Glycobiology. (2014) 24:1237-41. doi: 10.1093/glycob/cwu058

216. Horvat R, Hovorka A, Dekan G, Poczewski H, Kerjaschki D. Endothelial cell membranes contain podocalyxin-the major sialoprotein of visceral glomerular epithelial cells. J Cell Biol. (1986) 102:484-91. doi: 10.1083/jcb.102.2.484

217. Kershaw DB, Thomas PE, Wharram BL, Goyal M, Wiggins JE, Whiteside CI, et al. Molecular cloning, expression, and characterization of podocalyxinlike protein 1 from rabbit as a transmembrane protein of glomerular podocytes and vascular endothelium. J Biol Chem. (1995) 270:29439-46. eng. doi: 10.1074/jbc.270.49.29439

218. Sassetti C, Van Zante A, Rosen SD. Identification of endoglycan, a member of the cd34/podocalyxin family of sialomucins. J Biol Chem. (2000) 275:900110. doi: 10.1074/jbc.275.12.9001

219. Nielsen JS, McNagny KM. CD34 is a key regulator of hematopoietic stem cell trafficking to bone marrow and mast cell progenitor trafficking in the periphery. Microcirculation. (2009) 16:48796. doi: 10.1080/10739680902941737

220. Morgan SM, Samulowitz U, Darley L, Simmons DL, Vestweber D. Biochemical characterization and molecular cloning of a novel endothelial-specific sialomucin. Blood. (1999) 93:165-75. eng. doi: 10.1182/blood.V93.1.165

221. Kuhn A, Brachtendorf G, Kurth F, Sonntag M, Samulowitz U, Metze $\mathrm{D}$, et al. Expression of endomucin, a novel endothelial sialomucin, in normal and diseased human skin. J Invest Dermatol. (2002) 119:1388-93. eng. doi: 10.1046/j.1523-1747.2002.19647.x

222. Strilic B, Eglinger J, Krieg M, Zeeb M, Axnick J, Babal P, et al. Electrostatic cell-surface repulsion initiates lumen formation in developing blood vessels. Curr Biol. (2010) 20:2003-9. doi: 10.1016/j.cub.2010.09.061

223. Robbins RM, Beitel GJ. Vascular lumen formation: negativity will tear us apart. Curr Biol. (2010) 20:R973-5. doi: 10.1016/j.cub.2010.10.032

224. Bistrup A, Bhakta S, Lee JK, Belov YY, Gunn MD, Zuo FR, et al. Sulfotransferases of two specificities function in the reconstitution of high endothelial cell ligands for L-selectin. J Cell Biol. (1999) 145:899910. doi: $10.1083 /$ jcb.145.4.899

225. Mason JC, Curry FE, Michel CC. The effects of proteins upon the filtration coefficient of individually perfused frog mesenteric capillaries. Microvasc Res. (1977) 13:185-202. doi: 10.1016/0026-2862(77)90084-X

226. Reeves WH, Kanwar YS, Farquhar MG. Assembly of the glomerular filtration surface. differentiation of anionic sites in glomerular capillaries of newborn rat kidney. J Cell Biol. (1980) 85:735-53. doi: 10.1083/jcb.85.3.735

227. Betteridge KB, Arkill KP, Neal CR, Harper SJ, Foster RR, Satchell SC, et al. Sialic acids regulate microvessel permeability, revealed by novel in vivo studies of endothelial glycocalyx structure and function. J Physiol. (2017) 595:5015-35. doi: 10.1113/JP274167

228. Debruin EJ, Hughes MR, Sina C, Liu A, Cait J, Jian Z, et al. Podocalyxin regulates murine lung vascular permeability by altering endothelial cell adhesion. PLoS ONE. (2014) 9:E108881. doi: 10.1371/journal.pone.01 08881

229. Horrillo A, Porras G, Ayuso MS, Gonzalez-Manchon C. Loss of endothelial barrier integrity in mice with conditional ablation of podocalyxin (podxl) in endothelial cells. Eur J Cell Biol. (2016) 95:265-76. doi: 10.1016/j.ejcb.2016.04.006

230. Cait J, Hughes MR, Zeglinski MR, Chan AW, Osterhof S, Scott RW, et al. Podocalyxin Is required for maintaining blood-brain barrier function during acute inflammation. Proc Natl Acad Sci U S A. (2019) 116:45184527. doi: 10.1073/pnas.1814766116

231. Doyonnas R, Kershaw DB, Duhme C, Merkens H, Chelliah S, Graf T, et al. Anuria, omphalocele, and perinatal lethality in mice lacking the cd34-related protein podocalyxin. J Exp Med. (2001) 194:13-27. doi: 10.1084/jem.194.1.13

232. Song K, Fu J, Song J, Herzog BH, Bergstrom K, Kondo Y, et al. Loss of mucin-type o-glycans impairs the integrity of the glomerular filtration barrier in the mouse kidney. J Biol Chem. (2017) 292:164917. doi: 10.1074/jbc.M117.798512

233. Spinale JM, Ruebner RL, Kaplan BS, Copelovitch L. Update on streptococcus pneumoniae associated hemolytic uremic syndrome. Curr Opin Pediatr. (2013) 25:203-8. doi: 10.1097/MOP.0b013e32835d7f2c

234. Rothschild MA, Oratz M, Schreiber SS. Serum albumin. Hepatology. (1988) 8:385-401. doi: 10.1002/hep.1840080234

235. Carter DC, Ho JX. Structure of serum albumin. Adv Protein Chem. (1994) 45:153-203. doi: 10.1016/S0065-3233(08)60640-3

236. Sugio S, Kashima A, Mochizuki S, Noda M, Kobayashi K. Crystal structure of human serum albumin at 2.5 a resolution. Protein Eng. (1999) 12:43946. doi: 10.1093/protein/12.6.439

237. He XM, Carter DC. Atomic structure and chemistry of human serum albumin. Nature. (1992) 358:209-15. doi: 10.1038/358209a0

238. Leggio C, Galantini L, Pavel NV. About the albumin structure in solution: cigar expanded form versus heart normal shape. Phys Chem Chem Phys. (2008) 10:6741-50. doi: 10.1039/b808938h

239. Rondeau P, Bourdon E. The glycation of albumin: structural and functional impacts. Biochimie. (2011) 93:645-58. doi: 10.1016/j.biochi.2010.12.003

240. Filippov A, Artamonova M, Rudakova M, Gimatdinov R, Skirda V. Selfdiffusion in a hyaluronic acid-albumin-water system as studied by NMR. Magn Reson Chem. (2012) 50:114-9. doi: 10.1002/mrc.2853

241. Hedayati M, Reynolds MM, Krapf D, Kipper MJ. nanostructured surfaces that mimic the vascular endothelial glycocalyx reduce blood protein adsorption and prevent fibrin network formation. ACS Appl Mater Interfaces. (2018) 10:31892-1902. doi: 10.1021/acsami.8b09435

242. Osterloh K, Ewert U, Pries AR. Interaction of albumin with the endothelial cell surface. Am J Physiol Heart Circ Physiol. (2002) 283:H398405. doi: 10.1152/ajpheart.00558.2001

243. Clough G, Moffitt H. Immunoperoxidase labelling of albumin at the endothelial cell surface of frog mesenteric microvessels. Int J Microcirc Clin Exp. (1992) 11:345-58.

244. Schneeberger EE, Hamelin M. Interaction of serum proteins with lung endothelial glycocalyx: its effect on endothelial permeability. Am J Physiol. (1984) 247 (2 Pt 2):H206-17. doi: 10.1152/ajpheart.1984.247.2.H206

245. Fried TA, McCoy RN, Osgood RW, Stein JH. Effect of albumin on glomerular ultrafiltration coefficient in isolated perfused dog glomerulus. Am J Physiol. (1986) 250 (5 Pt 2):F901-6. doi: 10.1152/ajprenal.1986.250.5.F901

246. Mann GE. alterations of myocardial capillary permeability by albumin in the isolated, perfused rabbit heart. J Physiol. (1981) 319:31123. doi: 10.1113/jphysiol.1981.sp013910

247. Fujihara CK, Arcos-Fajardo M, Brandao De Almeida Prado E, Jose Brandao De Almeida Prado M, Sesso A, Zatz R. enhanced glomerular permeability to macromolecules in the nagase analbuminemic rat. Am J Physiol Renal Physiol. (2002) 282:F45-50. doi: 10.1152/ajprenal.2002.282.1.F45

248. Londono I, Ghitescu L, Bendayan M. Glomerular handling of circulating glycated albumin in the normal mouse kidney. Am J Physiol. (1995) 268 (5 Pt 2):F913-21. doi: 10.1152/ajprenal.1995.268.5.F913

249. Wilkerson BA, Grass GD, Wing SB, Argraves WS, Argraves KM. Sphingosine 1-phosphate (slp) carrier-dependent regulation of endothelial barrier: high density lipoprotein (hdl)-slp prolongs endothelial barrier enhancement as compared with albumin-slp via effects on levels, trafficking, and signaling of S1P1. J Biol Chem. (2012) 287:44645-53. doi: 10.1074/jbc.M112.423426

250. Zhang L, Zeng M, Fan J, Tarbell JM, Curry FR, Fu BM. Sphingosine-1phosphate maintains normal vascular permeability by preserving endothelial surface glycocalyx in intact microvessels. Microcirculation. (2016) 23:30110. doi: $10.1111 /$ micc. 12278 
251. Ruiz M. Into the labyrinth of the lipocalin alpha1-acid glycoprotein. Front Physiol. (2021) 12:686251. doi: 10.3389/fphys.2021.686251

252. Sorensson J, Matejka GL, Ohlson M, Haraldsson B. Human endothelial cells produce orosomucoid, an important component of the capillary Barrier. Am J Physiol. (1999) 276 (2 Pt 2):H530-4. eng. doi: 10.1152/ajpheart.1999.276.2.H530

253. Jorgensen HG, Elliott MA, Priest R, Smith KD. Modulation of sialyl lewis $\times$ dependent binding to e-selectin by glycoforms of alpha-1acid glycoprotein expressed in rheumatoid arthritis. Biomed Chromatogr. (1998) 12:343-9. doi: 10.1002/(SICI) 1099-0801(199811/12)12:6<343::AIDBMC760>3.0.CO;2-6

254. Ceciliani F, Pocacqua V. The acute phase protein alpha1-acid glycoprotein: a model for altered glycosylation during diseases. Current Protein \& Peptide Science. (2007) 8:91-108. doi: 10.2174/138920307779941497

255. Schnitzer JE, Pinney E. Quantitation of specific binding of orosomucoid to cultured microvascular endothelium: role in capillary permeability. Am J Physiol. (1992) 263 (1 Pt 2):H48-55. doi: 10.1152/ajpheart.1992.263.1.H48

256. Yuan W, Li G, Gil ES, Lowe TL, Fu BM. Effect of surface charge of immortalized mouse cerebral endothelial cell monolayer on transport of charged solutes. Ann Biomed Eng. (2010) 38:1463-72. doi: 10.1007/s10439-010-9920-x

257. Haraldsson B, Rippe B. Orosomucoid as one of the serum components contributing to normal capillary permselectivity in rat skeletal muscle. Acta Physiol Scand. (1987) 129:127-35. doi: 10.1111/j.1748-1716.1987.tb08047.x

258. Curry FE, Rutledge JC, Lenz JF. Modulation of microvessel wall charge by plasma glycoprotein orosomucoid. Am J Physiol. (1989) 257 (5 Pt 2):H13549. doi: 10.1152/ajpheart.1989.257.5.H1354

259. Yuan W, Li G, Zeng M, Fu BM. Modulation of the blood-brain barrier permeability by plasma glycoprotein orosomucoid. Microvasc Res. (2010) 80:148-57. doi: 10.1016/j.mvr.2010.03.011

260. Johnsson E, Haraldsson B. Addition of purified orosomucoid preserves the glomerular permeability for albumin in isolated perfused rat kidneys. Acta Physiol Scand. (1993) 147:1-8. doi: 10.1111/j.1748-1716.1993.tb09466.x

261. Hjalmarsson C, Lidell ME, Haraldsson B. Beneficial effects of orosomucoid on the glomerular barrier in puromycin aminonucleoside-induced nephrosis. Nephrol Dial Transplant. (2006) 21:1223-30. doi: 10.1093/ndt/gfk050

262. Christiansen MS, Iversen K, Larsen CT, Goetze JP, Hommel E, Molvig J, et al. Increased urinary orosomucoid excretion: a proposed marker for inflammation and endothelial dysfunction in patients with type 2 diabetes. Scand J Clinic Lab Investigat. (2009) 69:272-81. doi: 10.1080/00365510802531100

263. Watanabe H, Bi J, Murata R, Fujimura R, Nishida K, Imafuku T, et al. A Synthetic retinoic acid receptor agonist am 80 ameliorates renal fibrosis via inducing the production of alpha-1-acid glycoprotein. Sci Rep. (2020) 10:11424. doi: 10.1038/s41598-020-68337-z

264. Watanabe H, Fujimura R, Hiramoto Y, Murata R, Nishida K, Bi J, et al. An acute phase protein alphal-acid glycoprotein mitigates AKI and its progression to CKD through its anti-inflammatory action. Sci Rep. (2021) 11:7953. doi: 10.1038/s41598-021-87217-8

265. Siddiqi FS, Advani A. Endothelial-Podocyte crosstalk: the missing link between endothelial dysfunction and albuminuria in diabetes. Diabetes. (2013) 62:3647-55. doi: 10.2337/db13-0795

266. Sison K, Eremina V, Baelde H, Min W, Hirashima M, Fantus IG, et al. glomerular structure and function require paracrine, not autocrine, VEGF-VEGFR-2 signaling. J Am Soc Nephrol. (2010) 21:1691-701. doi: 10.1681/ASN.2010030295

267. Ebefors K, Wiener RJ, Yu L, Azeloglu EU, Yi Z, Jia F, et al. endothelin receptor-a mediates degradation of the glomerular endothelial surface layer via pathologic crosstalk between activated podocytes and glomerular endothelial cells. Kidney Int. (2019) 96:957-970. doi: 10.1016/j.kint.2019.05.007

268. Singh A, Satchell SC. Microalbuminuria: causes and implications. Pediatr Nephrol. (2011) 26:1957-65. doi: 10.1007/s00467-011-1777-1

269. Koyoshi R, Hitaka-Yoshimine Y, Shiga Y, Kuwano T, Sugihara M, Ike A, et al. Associations between microalbuminuria and parameters of flow-mediated vasodilatation obtained by continuous measurement approaches. Clinic Experim Hypertens. (2018) 40:715-20. doi: 10.1080/10641963.2018.1425422
270. Dogne S, Flamion B. endothelial glycocalyx impairment in disease: focus on hyaluronan shedding. Am J Pathol. (2020) 190:768-780. doi: 10.1016/j.ajpath.2019.11.016

271. Niu T, Zhao M, Jiang Y, Xing X, Shi X, Cheng L, et al. Endomucin restores depleted endothelial glycocalyx in the retinas of streptozotocin-induced diabetic rats. FASEB J. (2019) 33:13346-57. doi: 10.1096/fj.201901161R

272. Bignamini AA, Chebil A, Gambaro G, Matuska J. Sulodexide for diabeticinduced disabilities: a systematic review and meta-Analysis. Adv Ther. (2021) 38:1483-513. doi: 10.1007/s12325-021-01620-1

273. Yongwatana K, Supasyndh O, Satirapoj B. Renal effects of sulodexide in type 2 diabetic patients without nephrotic range proteinuria. J Diabetes Res. (2020) 2020:2984680. doi: 10.1155/2020/2984680

274. Olde Engberink RH, Heerspink HJ, de Zeeuw D, Vogt L. Blood pressurelowering effects of sulodexide depend on albuminuria severity: post hoc analysis of the sulodexide microalbuminuria and macroalbuminuria studies. Br J Clin Pharmacol. (2016) 82:1351-1357. doi: 10.1111/bcp.13062

275. Broekhuizen LN, Lemkes BA, Mooij HL, Meuwese MC, Verberne H, Holleman F, et al. Effect of sulodexide on endothelial glycocalyx and vascular permeability in patients with type 2 diabetes mellitus. Diabetologia. (2010) 53:2646-55. doi: 10.1007/s00125-010-1910-x

276. Heerspink HL, Greene T, Lewis JB, Raz I, Rohde RD, Hunsicker LG, et al. Effects of sulodexide in patients with type 2 diabetes and persistent albuminuria. Nephrol Dial Transplant. (2008) 23:194654. doi: $10.1093 / \mathrm{ndt} / \mathrm{gfm} 893$

277. Liew H, Roberts MA, McMahon LP. Markers of the Endothelial glycocalyx are improved following kidney transplantation. Kidney Blood Press Res. (2021) 28:1-7. doi: 10.1159/000517317

278. Liew H, Roberts MA, Pope A, McMahon LP. Endothelial glycocalyx damage in kidney disease correlates with uraemic toxins and endothelial dysfunction. BMC Nephrol. (2021) 22:21. doi: 10.1186/s12882-020-02219-4

279. Strevens H, Wide-Swensson D, Hansen A, Horn T, Ingemarsson I, Larsen $\mathrm{S}$, et al. Glomerular endotheliosis in normal pregnancy and pre-eclampsia. BJOG. (2003) 110:831-6. eng. doi: 10.1111/j.1471-0528.2003.02162.x

280. Gaber LW, Spargo BH, Lindheimer MD. Renal pathology in pre-eclampsia. Baillieres Clin Obstet Gynaecol. (1994) 8:443-68. doi: 10.1016/S0950-3552(05)80330-X

281. Spargo B, Mc CC, Winemiller R. Glomerular capillary endotheliosis in toxemia of pregnancy. Arch Pathol. (1959) 68:593-9.

282. Zununi Vahed S, Rahbar Saadat Y, Ardalan M. Thrombotic microangiopathy During pregnancy. Microvasc Res. (2021) 138:104226. doi: 10.1016/j.mvr.2021.104226

283. Eremina V, Baelde HJ, Quaggin SE. Role of the VEGF-a signaling pathway in the glomerulus: evidence for crosstalk between components of the glomerular filtration barrier. Nephron Physiol. (2007) 106:327. doi: $10.1159 / 000101798$

284. Eremina V, Sood M, Haigh J, Nagy A, Lajoie G, Ferrara N, et al. Glomerularspecific alterations of vegf-a expression lead to distinct congenital and acquired renal diseases. J Clin Invest. 2003 March 3;111 (5):707-16. eng. doi: 10.1172/JCI17423

285. Larrivee B, Prahst C, Gordon E, del Toro R, Mathivet T, Duarte A, et al. ALK1 signaling inhibits angiogenesis by cooperating with the notch pathway. Developmental Cell. (2012) 22:489-500. doi: 10.1016/j.devcel.2012. 02.005

286. David L, Mallet C, Keramidas M, Lamande N, Gasc JM, Dupuis-Girod S, et al. Bone morphogenetic protein-9 is a circulating vascular quiescence factor. Circ Res. (2008) 102:914-22. doi: 10.1161/CIRCRESAHA.107.1 65530

287. Maynard SE, Min JY, Merchan J, Lim KH, Li J, Mondal S, et al. Excess placental soluble fms-like tyrosine kinase 1 (sflt1) may contribute to endothelial dysfunction, hypertension, and proteinuria in preeclampsia. $J$ Clin Invest. (2003) 111:649-58. doi: 10.1172/JCI17189

288. Levine RJ, Lam C, Qian C, Yu KF, Maynard SE, Sachs BP, et al. Soluble endoglin and other circulating antiangiogenic factors in preeclampsia. $N$ Engl J Med. (2006) 355:992-1005. doi: 10.1056/NEJMoa055352

289. Chen Q, Wang Y, Li Y, Zhao M, Nie G. Serum podocalyxin is significantly increased in early-onset preeclampsia and may represent a novel marker of maternal endothelial cell dysfunction. J Hypertens. (2017) 35:228794. doi: $10.1097 /$ HJH.0000000000001461 
290. Cosmai L, Gallieni M, Liguigli W, Porta C. Renal toxicity of anticancer agents targeting vascular endothelial growth factor (vegf) and its receptors (VEGFRs). J Nephrol. (2017) 30:171-80. doi: 10.1007/s40620-016-0311-8

291. Lemaire M, Fremeaux-Bacchi V, Schaefer F, Choi M, Tang WH, Le Quintrec $\mathrm{M}$, et al. Recessive mutations in DGKE cause atypical hemolytic-uremic syndrome. Nat Genet. (2013) 45:531-6. doi: 10.1038/ng.2590

292. Liu D, Ding Q, Dai DF, Padhy B, Nayak MK, Li C, et al. Loss of diacylglycerol kinase epsilon causes thrombotic microangiopathy by impairing endothelial VEGFA signaling. JCI Insight. (2021) 6:59. doi: 10.1172/jci.insight.146959

293. Jokiranta TS. HUS and Atypical HUS. Blood. (2017) 129:28472856. doi: 10.1182/blood-2016-11-709865

294. Nolasco LH, Turner NA, Bernardo A, Tao Z, Cleary TG, Dong JF, et al. hemolytic uremic syndrome-associated shiga toxins promote endothelial-cell secretion and impair ADAMTs13 cleavage of unusually large von willebrand factor multimers. Blood. (2005) 106:4199-209. eng. doi: 10.1182/blood-2005-05-2111

295. Yamaoka-Tojo M. Vascular endothelial glycocalyx damage in COVID-19. Int J Mol Sci. (2020) 21:24. doi: 10.3390/ijms21249712

296. Zhang J, Tecson KM, McCullough PA. Endothelial dysfunction contributes to covid-19-associated vascular inflammation and coagulopathy. Rev Cardiovasc Med. (2020) 21:315-9. doi: 10.31083/j.rcm.2020.03.126

297. Tsai HM. The molecular biology of thrombotic microangiopathy. Kidney Int. (2006) 70:16-23. doi: 10.1038/sj.ki.5001535

298. Delvaeye M, Noris M, De Vriese A, Esmon CT, Esmon NL, Ferrell G, et al. Thrombomodulin mutations in atypical hemolytic-uremic syndrome. $\mathrm{N} \mathrm{Engl}$ J Med. (2009) 361:345-57. doi: 10.1056/NEJMoa0810739

299. Nadir Y. Heparanase in the coagulation system. Adv Experiment Med Biol. (2020) 1221:771-84. doi: 10.1007/978-3-030-34521-1_33

300. Loeven MA, Rops AL, Berden JH, Daha MR, Rabelink TJ, van der Vlag J. The role of heparan sulfate as determining pathogenic factor in complement factor h-associated diseases. Mol Immunol. (2015) 63:2038. doi: 10.1016/j.molimm.2014.08.005

301. Ballermann BJ. Endothelial cell activation. Kidney Int. (1998) 53:1810-26. eng. doi: 10.1046/j.1523-1755.1998.00943.x
302. Tsai HM, Raoufi M, Zhou W, Guinto E, Grafos N, Ranzurmal $\mathrm{S}$, et al. ADAMTS13-binding igg are present in patients with thrombotic thrombocytopenic purpura. Thromb Haemost. (2006) 95:886-92. doi: 10.1160/TH06-02-0100

303. Johansson PI, Stensballe J, Ostrowski SR. Shock induced endotheliopathy (shine) in acute critical illness-a unifying pathophysiologic mechanism. Crit Care. (2017) 21:25. doi: 10.1186/s13054-017-1605-5

304. Lipowsky HH. Role of the Glycocalyx as a barrier to leukocyteendothelium adhesion. Adv Experiment Med Biol. (2018) 1097:5168. doi: 10.1007/978-3-319-96445-4_3

305. Britten MW, Lumers L, Tominaga K, Peters J, Dirkmann D. Glycocalyx components affect platelet function, whole blood coagulation, and fibrinolysis: an in vitro study suggesting a link to trauma-induced coagulopathy. BMC Anesthesiol. (2021) 21:83. doi: 10.1186/s12871-021-01300-1

Conflict of Interest: The authors declare that the research was conducted in the absence of any commercial or financial relationships that could be construed as a potential conflict of interest.

Publisher's Note: All claims expressed in this article are solely those of the authors and do not necessarily represent those of their affiliated organizations, or those of the publisher, the editors and the reviewers. Any product that may be evaluated in this article, or claim that may be made by its manufacturer, is not guaranteed or endorsed by the publisher.

Copyright (C) 2021 Ballermann, Nyström and Haraldsson. This is an open-access article distributed under the terms of the Creative Commons Attribution License (CC BY). The use, distribution or reproduction in other forums is permitted, provided the original author(s) and the copyright owner(s) are credited and that the original publication in this journal is cited, in accordance with accepted academic practice. No use, distribution or reproduction is permitted which does not comply with these terms. 